Max-Planck-Institut für demografische Forschung

Max Planck Institute for Demographic Research

Konrad-Zuse-Strasse 1 - D-18057 Rostock - GERMANY

Tel +49 (0) 3812081 - 0; Fax +49 (0) 3812081 - 202;

http://www.demogr.mpg.de

MPIDR WORKING PAPER WP 2012-024

AUGUST 2012

\title{
Normative and Allocation Role Strain: \\ Role Incompatibility, Outsourcing, and the Transition to a Second Birth in Eastern and Western Germany
}

Liat Raz-Yurovich (raz@demogr.mpg.de)

This working paper has been approved for release by: Michaela Kreyenfeld (kreyenfeld@demogr.mpg.de), Deputy Head of the Laboratory of Economic and Social Demography.

(C) Copyright is held by the authors.

Working papers of the Max Planck Institute for Demographic Research receive only limited review. Views or opinions expressed in working papers are attributable to the authors and do not necessarily reflect those of the Institute. 


\title{
Normative and Allocation Role Strain: Role Incompatibility, Outsourcing, and the Transition to a Second Birth in Eastern and Western Germany
}

\author{
Liat Raz-Yurovich ${ }^{1}$
}

\begin{abstract}
The challenges women face in reconciling their work and family responsibilities are at the heart of current explanations concerning the low fertility levels in developed countries. This study examines the role of the outsourcing of household labor and of childcare responsibilities in reducing the incompatibility of women's roles and in increasing fertility in the two different institutional and normative contexts of Eastern and Western Germany. Using the German Socio-Economic Panel, we analyzed whether Eastern and Western German women who outsourced childcare responsibilities to formal and informal care providers in the first and in the third years after the first birth were at higher risk of having a second child. Drawing on Goode’s role strain theory, we suggest that the incompatibility of women's roles is affected not only by allocation role strain, but also by normative role strain. Our results indicate that the outsourcing of childcare to formal providers and to grandparents reduces, rather than increases, the propensity to have a second child among Western German women, due to normative role strain. We also find a significant positive effect of the outsourcing of housework on the transition to a second birth in Germany, due to the decline in allocation role strain.
\end{abstract}

\footnotetext{
${ }^{1}$ Laboratory of Economic and Social Demography, Max Planck Institute for Demographic Research. (raz@demogr.mpg.de, liat.raz@mail.huji.ac.il)
} 


\section{Introduction}

One of the most common explanations given in the demographic literature for the low fertility levels in most developed countries is the rapid increase in women's participation in the paid labor force. The mechanism behind the negative relationship between women's employment and fertility, it is claimed, is the incompatibility of these roles that women feel after entering the labor force, which results in delaying and foregoing having children (Frejka and Calot, 2001; Rindfuss and Brewster, 1996). Rindfuss and Brewster (1996) argued that, as role incompatibility-i.e., women's difficulties in balancing their work and family responsibilities—-mediates the relationship between female labor force participation and fertility, this association may be expected to diminish as the conflicts between the mother and the worker roles are reduced. In line with this argument, macro-level studies that analyzed the change in the relationship between women's employment and fertility over time, as well as across and within different institutional contexts, attributed the change and variation in this relationship to shifts over time in the incompatibility of family and work roles. These scholars also cited the variation in the institutional barriers women face while trying to maintain the two roles as a contributing factor in this change (Brewster and Rindfuss, 2000; Engelhardt et al., 2004; Kravdal and Rindfuss, 2008; Rindfuss et al., 2003).

Brewster and Rindfuss (2000) suggested that structural mechanisms, such as family policies concerning cash benefits and parental leave, the availability of childcare, and labor market arrangements, might affect the degree of role incompatibility women face in different countries. Therefore, they argued, policy changes can help to reduce role incompatibility, and thereby increase fertility. Moreover, Torr and Short (2004) suggested that gender equity at home might also 
influence fertility by improving women's work-life balance. If men were to increase their share of childcare and housework, the burden on women would be somewhat reduced, and women would be better able to combine work and family life. A positive association between men's contribution to either housework or childcare and the probability of having a second child has been found among couples in Italy, Hungary, Sweden, and the UK (Cooke, 2008; Olah, 2003; Schober, 2012). A curvilinear effect, with very traditional couples and highly egalitarian couples experiencing the highest risk of a second birth, has been found for the US and Germany (Cooke, 2004; Torr and Short, 2004).

In the current study, we will investigate whether the outsourcing of childcare and household tasks is another mechanism that could serve to attenuate the impact of role incompatibility on women’s decisions about childbearing.

\section{Outsourcing and Fertility}

A growing body of literature has suggested that the increasing ability of women to outsource housework and childcare duties, either by buying services or by using social networks, serves as a mechanism for reducing role incompatibility, and is positively related to women's labor force participation and fertility. Macro-level studies have demonstrated that, by purchasing services, highly skilled women with the highest opportunity costs in terms of time can increase their labor supply and reduce the time spent on housework and childcare. This is possible partially due to the supply of low-skilled immigrants who work in services that are close substitutes to household production. Evidence for the relationship between the availability of low-skilled immigrants and women's labor force participation is available for both industrialized countries, such as the US (Cortès and Tessada, 2009), Italy (Barone and Mocetti, 2011), and Spain (Farrè et al., 2009); and for newly industrialized societies, such as 
Hong Kong (Chan, 2006; Cortès and Pan, 2008) and Singapore (Yeoh et al., 1999). Furtado and Hock (2008) demonstrated that the continuing influx of low-skilled immigrants to the US affected not only women's economic activity, but also their fertility. They showed that the immigrant-led decline in the price of childcare has reduced the extent of role incompatibility among highly educated native women, because childcare became more affordable for them.

In the European context, where the availability of publically provided childcare arrangements is more important for the decision to outsource childcare than their cost (Hank and Kreyenfeld, 2003), the coverage rates of public childcare for children aged 0-2 is found to affect fertility in Italy (Del Boca, 2002) but not in Western Germany (Hank and Kreyenfeld, 2003).

Micro-level studies from the Netherlands and the US further demonstrated that couples use the outsourcing of domestic work as a strategy for combining work and family life (De Ruijter and Van der Lippe, 2007, Oropesa, 1993; Van der Lippe et al., 2004).

The ability to outsource household labor and childcare is in most cases income-dependent, and therefore might affect fertility only among highly skilled women. However, a growing body of literature has pointed to another way that women can use to outsource childcare responsibilities, which is not income-dependent and can be regarded as an informal form of outsourcing. Previous studies suggested that the rigidity and limitations of the supply of publicly provided childcare arrangements are compensated for by a substantial family support system (Del Boca, 2002; Hank and Kreyenfeld, 2003; Philipov et al., 2006). This literature has emphasized the role of the availability of social networks, which can serve as childcare support systems, in increasing fertility or fertility intentions. Hank and Kreyenfeld (2003), for example, found higher first-birth risks between the 1980s and 
the 1990s among Western German women whose parents lived in the same town. In a qualitative study, Keim et al. (2009) found that being able to draw upon parental support fosters family formation in Germany, while a lack of support is a factor that hampers it. Moreover, siblings, cousins, and friends were found to provide casual support with childcare. Studies on Eastern European countries—such as Bulgaria, Hungary, Poland, and Russia — demonstrated a positive effect of social capital as a support system on fertility intentions (Philipov and Shkolnikov, 2001; Bühler and Fratczak, 2004; Bühler and Fratczak, 2005; Bühler and Philipov, 2005; Philipov et al., 2006). A positive effect was also found for Germany (Ette and Ruckdeschel, 2007). Social and family networks as a source of help with childcare can also be considered as a more trustful care providers, as family ties are characterized by loyalty and altruism, which limits opportunistic behavior, dishonesty and mistrust (Pollak, 1985). It is important to note that, in some respects, the outsourcing behavior can be regarded as the flip side of the provision of services by the public or by the private markets; i.e., that the practice of outsourcing is solely dependent on the provision and the availability of services, an aspect that has been discussed in the literature on role incompatibility. However, the outsourcing of, for example, childcare tasks might be dependent on norms and values regarding mothers' roles and children's welfare (Kremer, 2006). This means that, if the prevailing norm in the society is that children should be cared for by their mothers until a certain age, a wider deployment of childcare facilities would not necessarily affect women’s decisions to outsource childcare duties to institutional providers. Moreover, drawing on Coale’s (1973) traditional theoretical model for the success of innovative behavior, the availability of affordable and high-quality childcare facilities might be a necessary, but not a sufficient precondition for the use of such facilities in a certain society. According to this model, the outsourcing of childcare responsibilities to childcare facilities might 
become a common behavior in the society if another two preconditions are met: 1 . profitability: mothers perceive that using childcare facilities, rather than taking care of the child at home, yields benefits which overweigh the costs or disadvantages of using such arrangements; and 2. acceptability: the use of childcare arrangements is perceived at the societal level as a legitimate substitute for the mother's care, and is culturally, ethically, and morally acceptable. Therefore, the supply and the demand aspects of institutional arrangements are closely related, but are also affected by other mechanisms, such as values and attitudes concerning children's welfare and gender roles.

As in reality there is a high degree of overlap between prevailing gender ideologies and family policies, empirically it is hard to identify contexts in which the state offers childcare services but the society is not willing to accept them. However, in this study we do not analyze the use of childcare, but rather we use the case of Eastern and Western Germany - two formerly disconnected entities that developed different cultural and institutional approaches to the roles of mothers - in order to examine the way in which norms might condition the way actual outsourcing of childcare and domestic chores affect role incompatibility and fertility. We choose to analyze both the outsourcing of childcare and the outsourcing of housework because we believe these two tasks differ in the level of normative approbation to their delegation in the German society. As will be discussed later, we assume that in the German society there are stronger normative barriers to the delegation of childcare relative to housework. Moreover, we further assume that the normative barriers to the delegation of childcare are stronger in Western Germany relative to Eastern Germany, but that there are no significant differences between the regions with regard to the normative barriers to the outsourcing of housework. In the analysis of the outsourcing of childcare we distinguish between outsourcing to formal and to informal sources of 
help. It is important to distinguish between the two types of help with childcare, because it is possible that if we will find a negative effect of the use of formal childcare on fertility it will be due to issues of mistrust and not due to normative perceptions. This means that women who choose to use formal childcare which they do not fully trust will feel an increase in roll strain which will negatively affect their propensity to have a second child; but women who use an altruistic and loyal source of help, such as grandparents, will experience a reduction in roll strain. We assume that if the outsourcing to both formal and informal sources of help will be resulted in a negative effect on the transition to a second birth, it will buttress our argument regarding the existence of a conditioning effect by norms.

The previous literature on the relationship between fertility and the outsourcing of household labor and childcare tasks, as described above, relied either on macro-level analyses (e.g., Furtado and Hock, 2008), or on micro-level analyses that are cross-sectional (e.g., Bühler and Philipov, 2005; Philipov et al., 2006). Moreover, the micro-level studies on social networks and fertility mostly focused on fertility intensions rather than actual fertility (e.g., Bühler and Philipov, 2005; Philipov et al., 2006), and sometimes used indirect measures of social support, such as whether the women's parents lived in the same town (Hank and Kreyenfeld, 2003) or whether they are alive (Del Boca, 2002). To address these shortcomings, in the current study we employ a life-course perspective to analyze whether German women who outsource domestic work to a paid domestic helper after the first birth, and whether Western and Eastern German women who outsource childcare tasks to formal childcare providers and/or to social networks after the first birth, have higher second birth rates. Taking a life-course approach, for the analysis of the way in which the outsourcing of childcare affects the woman's propensity to have a second child, we focus on two critical junctures in the mother's life: when her first child is aged 0- 
1, and again when her first child is aged 2-3. Based on the assumption that the first three years after becoming a mother for the first time are the most demanding in terms of the care that must be provided; the amount of stress—or stress relief—women experience in these years will color their experiences of the mother's role, and will affect their willingness to have an additional child. For the analysis of the outsourcing of housework we will focus not only on the first few years after the first birth, but rather on the whole period between the first and the second birth, if it occurred; assuming that the housework load might increase as the child grows up.

\section{Theoretical Considerations}

Two main theoretical assumptions are at the heart of the argument about the incompatibility of women's roles. The first is Coser's theoretical perception of work and family as "greedy institutions," which make total claims on their members and demand exclusive commitment and loyalty (Coser, 1974). The second theoretical basis of the role incompatibility argument is Goode's (1960) role strain theory. This theory has three basic assumptions: 1) taking on multiple roles is very demanding and creates role strain ${ }^{2}$ for the individual; 2) the organizational structure of the roles is hierarchical, and the individual will assign more importance to certain roles than to others, and 3) the individual bargains between the roles in order to minimize the role strain. According to this theory, if the woman's roles in the family, in the workplace, and in other social institutions compete and are very demanding, she might feel role strain while trying to satisfy the demands of all these roles. In order to reduce this feeling of role strain, the woman will continuously engage in a process of role decisions and bargains in which she selects among role behaviors. Some of the mechanisms that a woman can use in order to reduce the role strain, according to

\footnotetext{
2 “The felt difficulty in fulfilling role obligations” (Goode, 1960: 483).
} 
Goode (1960), are: 1. compartmentalization, in which, for example, the woman maintains a full separation between work and family life in order to avoid a spillover between the two spheres; 2 . delegation, in which the woman outsources some of the domestic tasks, such as the household chores and some of the childcare responsibilities, to a service provider or to other people, thus making her role as a mother less demanding; 3 . the elimination or reduction ${ }^{3}$ of role relationships, i.e., in order to reduce the role strain which results from her roles in the family and in the workplace, the woman can choose either to remain childless or to not have additional children, or to fully withdraw from the labor market or quit her demanding job and find a more family-friendly job; and 4. extension, in which the woman expands her role relations and finds a job which allows her to work for a salary while she is taking care of her child (working from home, for example). All of these strain-reduction techniques suggest different strategies for allocating the women's commitments in a way that will produce a minimum level of strain. Thus, these aspects of Goode's theory mostly refer to the role strain which arises due to the inappropriate allocation of commitment and time. Based on these aspects in Goode's theory the effect of outsourcing on fertility should be as follows:

The outsourcing of domestic and care tasks should positively affect the transition to a second birth by reducing the allocation role strain among first-time mothers.

In this study, we would also like to highlight another, normative aspect of role strain, which is hinted at by Goode's role strain theory. Goode's theory implies the

\footnotetext{
${ }^{3}$ Strategies for reducing work and family role relationships were also described as "scaling back" strategies in the literature (Becker \& Moen, 1999).
} 
existence of a normative role strain, which arises when a woman occupies a role or a set of roles which are not culturally acceptable for women. According to Goode, an individual's ability to manipulate his or her role structure is dependent on the social structure and on the prevailing norms in the society. For example, the societal hierarchy of values indicates which domestic or childcare tasks cannot be delegated or outsourced by mothers. Goode (1960) further suggested that family relations are a set of role obligations which are less prone to bargaining. Moreover, a withdrawal from family roles is difficult, as doing so might inspire guilt feelings in the individual, and lead to social pressure on the individual to fulfill her (or his) family roles. Based on this aspect in Goode's theory we can expect the effect of outsourcing on fertility to be as follows:

If there are normative barriers to the delegation of a task, the outsourcing of this task will negatively affect the transition to a second birth by increasing the normative role strain among first-time mothers.

It is important to note that several alternatives to the role strain theory have been offered by the sociological literature; among them are Marks’ (1977) expansion approach, Sieber's (1974) role accumulation theory, and Marks' and MacDermid's (1996) role balance theory. Both Marks (1977) and Seiber (1974) criticize Goode’s assumptions regarding the allocation role strain. Marks (1977) resists Goode’s assumption that human energy, time and commitment are limited goods and suggests that these goods can be expanded or contracted according to the systems of commitments that determine their availability. Sieber (1974) suggests that role accumulation might be more gratifying than stressful. However, in line with Goode’s theory, both of them acknowledge the existence of normative or societal barriers to the ability to allocate time and energy or to the ability to accumulate roles. Marks 
(1977) suggests that systems of commitments might differ by structural determinants, and may have socially stratified dimensions. Moreover, Sieber (1974) argues that structural limitations might inhibit role accumulation. Marks' and MacDermid's (1996) role balance theory rejects the hierarchical nature of Goode’s role structure, and posits instead a new role organization, a role balance, in which an individual is fully engaged in the performance of all the roles in his or her role system. Unlike the other theories, the role balance theory does not consider the existence of normative or societal barriers to the ability to balance between roles.

\section{The German Context}

In addition to the fact that Germany is a developed country with a below-replacement fertility level, the profound current demographic, economic, and institutional differences between Eastern and Western Germany makes Germany a very interesting laboratory in which to explore the role of outsourcing in attenuating the relationship between role incompatibility and fertility. According to Goldstein and Kreyenfeld (2011), the two German regions have, in many respects, never converged in their demographic, economic, and cultural characteristics after reunification. In terms of economics, Eastern Germany still has higher unemployment rates, lower wages, and less wealth than Western Germany, which make women's earnings a necessity for the family income. Moreover, the two regions are characterized by different attitudes toward maternal employment. While employment policies during the German Democratic Republic (GDR) regime emphasized full-time employment for women; the primary aim of policy makers in Western Germany was to enable and actively encourage mothers to stay home and care for their young children during the first years of life, and to maintain the traditional male breadwinner model (Erler, 2009; Rosenfeld et al., 2004). According to Goldstein and Kreyenfeld (2011) these different 
family models persisted after reunification: while maternal employment is common in Eastern Germany, where 58\% and 50\% of the mothers with at least one child aged 18 or younger worked full-time in 2000 and 2008, respectively; in Western Germany, working is still perceived to have an adverse effect on the well-being of children, and the full-time employment rates of mothers have been much lower, at 20\% in 2000 and 19\% in 2008. As Geisler (2010) further demonstrated, the differences in the employment characteristics of the Western and Eastern mothers remain after controlling for the age of the youngest child. One of the incentives for maintaining the male-breadwinner model among current Western German households stems from the joint taxation system. This system allows married couples to claim their income taxes together; i.e., the spouses' incomes are added together, divided by two, and then taxed as individual incomes with a progressive tax schedule. Therefore, married couples living in a single-male-earner arrangement have the greatest splitting advantage (Steiner and Wrohlich, 2004). Because men’s wages in Western Germany are much higher than in Eastern Germany, this model is much more beneficial to families in the West. According to Kreyenfeld (2002), the German health care and pension systems offer another incentive to maintain single-earner families, as married housewives are automatically insured by the health insurance of their husbands, and are entitled to a widow's pension.

Eastern German women also benefit from a more equal division of household labor. According to Davis and Greenstein (2004) 75.4\% of Eastern German women, but $87.1 \%$ of Western German women, reported in a 1991 survey that the housework is usually or always done by them. In addition, our own calculations using the ISSP 2002 database (ISSP, 2002) showed that Western German women have much more conservative attitudes about gender roles and women's roles as mothers and workers. Table 1 shows, for example, that a lower percentage of Western than Eastern German 
women agree or strongly agree that a working mother can establish just as warm and secure a relationship with her children as a mother who does not work; and that both men and women should contribute to the household income. Moreover, a higher percentage of Western than Eastern German women agree or strongly agree that a pre-school child is likely to suffer if his or her mother works; that family life suffers when the woman has a full-time job; that a job is all right, but what most women really want is a home and children; and that being a housewife is just as fulfilling as working for pay. In addition, a higher percentage of Western German

[Table 1 here]

women agree or strongly agree that men ought to do a larger share of childcare than they do now. The attitudes toward women's work outside the home in different stages over the life course also differ between Western and Eastern German women. As Figure 1 illustrates, there are profound differences between the normative perceptions held by Western and Eastern German women regarding mothers’ employment. Western German women generally perceive full-time employment over the life course as an appropriate path for women to a lesser degree than Eastern German women. Moreover, Western German women approve of full-time employment for women only before they have children or after the children leave home. When there is a preschool or a school-age child at home, a higher percentage of the Western German women think that the woman should not work at all, and a higher percentage of the Eastern German women think that the woman should work at least part-time.

[Figure 1 here]

Goldstein and Kreyenfeld (2011) further demonstrated that public childcare provision is much higher in Eastern than in Western Germany, and that the use of 
childcare facilities differs between the two regions. While $37 \%$ and $41 \%$ of the Eastern German children aged 0-2 were in day care in 2000 and 2008, respectively; only $3 \%$ and $12 \%$ of the Western German children were in day care in the two respective years. Due to the wider availability of publically financed childcare arrangements in Eastern Germany, Eastern German mothers have shorter employment interruptions after the birth of a child, and they more frequently return to full-time employment than mothers in Western Germany (Trappe and Sørensen, 2006). According to Krapf (2010; 2012), these differences stem from the different childcare policies in the two regions. While full-time childcare facilities for children under the age of three were widely provided in Eastern Germany before reunification, these facilities were hardly available in Western Germany. Moreover, according to Erler (2009), public childcare provision was a political taboo in Western German family policies. Krapf (2010; 2012) further noted that the right to a kindergarten place for children aged 3-5 was not introduced until 1996, and then for only for half a day; while in Eastern Germany, full-day kindergarten places were widely provided even before reunification. In 2005, the German government initiated an expansion of childcare provision for children under the age of three, and in 2006 a tax deduction for childcare fees was introduced. By 2013, the legal entitlement to childcare will start at age one, and, across Germany, at least 35\% of children below the age of three will receive publicly provided childcare. However, as structural and cultural adjustments take time, the profound differences in the usage of such facilities in Eastern and Western Germany remain (Kreyenfeld and Krapf, 2010). Kreyenfeld and Hank (2000) further noted that private childcare providers can hardly be found in Germany due to heavy regulations, high market barriers to entry, and the dominance of public providers. Thus, the availability of childcare facilities might be more important than their affordability in the German context. 
With regard to fertility, Goldstein and Kreyenfeld (2011) showed that, although the fertility level converged at 1.6 children per woman in the period of 20012008, the two regions still differ in some respects. First, mothers in Western Germany tend to postpone childbearing more than mothers in Eastern Germany. In 2008, the average age at first birth was 27.5 among mothers in Eastern Germany and 28.7 among mothers in Western Germany. At the time of the second birth, also in 2008, the average age of mothers in Eastern Germany was 30.7, and the average age of mothers in Western Germany was 31. In addition to postponing childbearing, Western German women also tend to forgo having children at higher rates than Eastern German women. Among the 1960-64 birth cohort, 12\% of Eastern German women remained childless at age 45 , compared with $21 \%$ of the Western German women. While the first-order fertility rates in Eastern Germany were higher than in Western Germany during 2002-2008, the second-order fertility rates in Eastern Germany were lower than in Western Germany, and the rates converged only towards the end of this period, in 2008.

Another interesting difference between the two regions is in the ratio of nonmarital births. Kreyenfeld and Bastin (2010) demonstrated that, among the cohort of women who were born in 1971-73, 69\% of the Western German women, but only $36 \%$ of the Eastern German women, were married at the time of the first birth. At the time of the second birth, these differences had narrowed, with $85 \%$ of the Western and $61 \%$ of the Eastern German women being married at the time of the birth. The low marriage rates in Eastern Germany do not mean that these women are single mothers, as $43 \%$ of the Eastern German women, relative to $19 \%$ of the Western German women, reported being unmarried, but living with a partner at the time of the first birth. These percentages fell to $28 \%$ in the East and $9 \%$ in the West at the time of the second birth. 
The German parental leave policy that applies to our research period (19992006) included components of maternal and parental leaves. Overall, the parental leave period lasted 36 months, and included three years of protection against dismissal from the previous workplace; two months of maternity leave at the beginning of the period, right after birth; and a parental leave benefit of up to two years. According to Erler (2009), the maternity leave, which started immediately after birth and lasted for eight weeks, could only be taken by the mother. During these weeks, the mother was not allowed to work and received $100 \%$ of her average salary in the three months that preceded the maternity protection period ${ }^{4}$, with no ceiling, but with a minimum of $€ 13$ per day. Women who had not been working prior to childbirth were entitled to a minimum parental leave benefit payment of €300 per month. The parental leave period could be used by both partners, and the partner who was on leave was entitled to a childrearing benefit of $€ 300$ per month. Starting in 2001, the parents could choose whether to receive a monthly benefit of $€ 450$ for a period of one year, or to receive a monthly benefit of $€ 300$ for a period of two years. The parent who received this benefit could work up to 19 hours per week in the period prior to 2001; and up to 30 hours per week starting in 2001. Therefore, part-time employment was permitted during this period. Eligibility to receive the childrearing benefit was income-dependent, and individuals with high earnings, or whose spouse had a high income, were not entitled to receive this benefit. Erler (2009) further showed that, under this policy, the leave entitlement was mostly used by the mothers and not the fathers, as the opportunity cost of staying home with a child rather than working was much higher for men due to the gender wage gap. Moreover, these parental leave policies did not encourage women to shorten their leave period, and, in a sense,

\footnotetext{
${ }^{4}$ The maternity protection period started six weeks before the due date. In these six weeks, the woman could choose whether or not to work.
} 
encouraged career interruptions among women. This was especially true for women in Western Germany, where childcare facilities for children under the age of three were not widely available, and women were forced to remain at home for a long period after childbirth. It is important to note that, starting in 2007, a new income-related parental leave benefit, similar to the Scandinavian countries' leave benefit, was implemented. This benefit is designed to increase the father's use of parental leave, and to shorten the amount of time women stay home on leave. However, because we only refer to first births that occurred between 1999 and 2006, this change in policy is beyond the scope of this research.

\section{Hypotheses}

The institutional and normative differences between Eastern and Western Germany as are described above suggest that the outsourcing of childcare by first-time mothers ought to be culturally-sensitive; but if culture does not actually matters, the outsourcing of childcare will have a positive effect on fertility both in Eastern and in Western Germany due to the reduction in the allocation role strain.

Hypothesis 1: The outsourcing of childcare will have a positive effect on the transition to a second birth both in Eastern and in Western Germany.

However, if culture does matter, we expect that the more hours the first child is being taken care of by other people, other than the mother (no matter if it is a formal or an informal source of care) the less likely the mother will have a second child in Western

Germany due to the increase in the normative role strain among the Western mothers. Among Eastern German mothers we expect a positive effect of the outsourcing of childcare, due to the decline in the allocation role strain. 
Hypothesis 2: The outsourcing of childcare will have a negative effect on the transition to a second birth among Western German women; but will have a positive effect among Eastern German mothers.

As women who choose to work after the first birth presumably experience higher role strain than women who do not work, we expect the effect of the outsourcing on fertility to be stronger among them. This means that if women feel strain relief due to the reduction in the allocation role strain, this effect will be stronger among the working women. Moreover, if women feel an increase in the normative role strain when outsourcing childcare responsibilities, the negative effect of the outsourcing of childcare on fertility will be even stronger among the working women.

Hypothesis 3: The effect of the outsourcing of childcare will be stronger among working women, relative to non-working women, both in Eastern and in Western Germany.

Because we assume that there are fewer normative barriers to the outsourcing of housework relative to the outsourcing of childcare in Germany; and because we assume that there are no differences between the two German regions with regard to the normative barriers to the outsourcing of domestic chores, we expect the outsourcing of housework by first-time mothers in Eastern and Western Germany to have a positive effect on their propensity to have a second child.

Hypothesis 4: The outsourcing of housework will have a positive effect on the transition to a second birth both in Eastern and in Western Germany.

As in the case of childcare, we expect the effect of the outsourcing of housework on fertility to be stronger among working mothers, relative to non-working mothers. 
Hypothesis 5: The effect of the outsourcing of housework will be stronger among working women, relative to non-working women, both in Eastern and in Western Germany.

\section{Method}

Data, Samples, and Methods

This study uses data from the German Socio-Economic Panel (GSOEP), which has been interviewing households annually since 1984. Currently, this dataset provides longitudinal information for the period $1984-2010 .^{5}$ This database is based on different types of questionnaires for each year, such as household, individual, and mother-child questionnaires. These questionnaires include a battery of questions at the individual and at the household level, such as questions about employment, earnings, education, birth history, health, and marital status at the individual level; and questions about income, household composition, and whether the household employs a domestic helper at the household level. The mother-child questionnaires provide, among other things, age-specific information on the childcare arrangements for each child when the child is aged $0-1,2-3,5-6$, and 7-8. This information is not available for the time in which the child is 1-2 years old. For some variables, such as the employment status of the individual, the GSOEP provides monthly information.

In order to investigate the relationship between women's ability or tendency to outsource childcare and household labor after the first birth and the transition to a second birth, we use two analytic samples, so that one is a sub-sample of the other. For the analysis of the outsourcing of childcare tasks, we use a sample of 539 German women (73\% of them are from West Germany, and 27\% are from East Germany),

\footnotetext{
${ }^{5}$ For more information on the GSOEP, please visit http://www.diw.de/en/diw_02.c.238114.en/questionnaires_fieldwork_documents.html
} 
who gave birth for the first time in the years 2002-2006. Based on these women’s characteristics in the first and the third years after the birth of the first child, and based on information concerning the availability of help with childcare from different sources in these two years, we analyze whether a second birth had occurred by the year 2009 using a multivariate logistic regression analysis. Earlier time periods could not be included in the analysis because age-specific information on childcare arrangements, for newborns and for children aged 2-3, is available only starting in 2003, based on the birth cohorts 2002/2003. Overall, 44\% of the Western German women had given birth for the second time by 2009, compared to 34\% of the Eastern German women. Among the women who had given birth for the second time by 2009, the average time that had elapsed between the two births did not differ significantly between the two regions: 2.8 years in the West and 3.1 years in the East. The regression models for this analysis will be presented by region (Western and Eastern Germany) and years after the first birth (first year and third year after the birth of the first child; i.e., when the first child is aged 0-1 and 2-3, respectively). For each year, two regression models will be presented, with and without interaction terms between the woman's employment status in the relevant year and the amount of childcare help, measured in time, she received from each source. The first models are used to test the first and the second hypotheses. The second models, with the interaction term, are used to test the third hypothesis.

For the analysis of whether the outsourcing of household labor affects the transition to a second birth, we use a larger analytic sample, of 1,394 women who gave birth for the first time in the years 1999-2006. Earlier periods could not be included in the analysis because the information on whether the household employs a domestic helper is available in the GSOEP only starting in 1999. Each woman contributes exposure to a second birth starting with the first birth and until the second 
birth occurs, or until the year 2009 (the end of the research window). Overall, 45\% of the women had given birth for the second time by 2009. The women in this sample contribute 8,440 years of exposure to the second birth, which are analyzed using discrete-time event history analysis. The event-history models will be analyzed in two separate models, with and without interaction terms between employing a domestic helper and health status in year $t^{6}$; and between employing a domestic helper and the woman's employment status. The first model is used to test the fourth hypothesis, and the second model is meant to test the fifth hypothesis. The advantage of using the second analytic sample for the analysis of the effect of employing a domestic helper is mainly in the larger sample size. Moreover, for this sample, we use event-history analysis to refer to the whole period between the first and the second birth, if a second birth had occurred by 2009. Because in the event-history models we refer to the whole period between the first and the second birth, the model will not be presented separately for Eastern and Western German women, but will include a dummy for region to allow for the possibility of internal migration between the two regions during this period.

The two samples of women do not include women who gave birth to twins in the first birth.

\section{Variables}

Our dependent variable in the logistic regression is a binary variable which receives the value one if a second birth had occurred by 2009, and the value zero otherwise. In the event-history models, it is a binary variable that receives the value one if a second birth had occurred in year $t$, and the value zero otherwise.

\footnotetext{
${ }^{6}$ For an explanation of the need in this interaction term, please see the description of the health status variable in the variables section.
} 
Sources of help with childcare in the first year and the third year after the first birth This set of variables is included only in the logistic regression analysis, and includes the following information on help with childcare:

Number of weekly hours of childcare provided by the spouse - The number of hours the spouse invests in childcare in a normal week.

Number of weekly hours of childcare provided by the grandparents - The number of hours the grandparents of the child invest in childcare in a normal week. Number of weekly hours of childcare provided by other relatives or friends - The number of hours the older siblings of the child, other relatives, friends, or other people invest in childcare in a normal week.

Number of weekly hours of childcare provided by a formal childcare provider - The number of hours of childcare the child receives from a child minder ("Tagesmutter" or "Kinderfrau”) or a day care center (“Krippe," "Kindergarten,” or

“Kindertageseinrichtung”) in a normal week.

\section{Outsourcing of household labor}

The following variable is included only in the event-history models:

Employs domestic help in year $t$ - This variable indicates whether the household employs household help in year $t$. It receives the value one if the household regularly or occasionally employs such services, and the value zero if not. In order to ensure that the hiring of domestic services in the year of the second birth happened prior to the second birth and not after it; in the year of the second birth, the domestic help variable is computed in the following way: if the interview of the household in this year was conducted in the months prior to the second birth, we use the report on employing domestic help for the year t (i.e., the report given for the year in which the 
second birth occurred); and if the interview of the household was conducted in the months after the second birth, we impute the value that was given for the year t-1 (i.e., the report on hiring domestic help for the year prior to the year of the second birth).

Overall, $11 \%$ of the women who lived in Western Germany after the first birth had ever employed domestic help, compared to 6\% of the women who lived in Eastern Germany.

\section{Employment status}

This variable is constructed differently for the two analyses. For the logistic regression analysis, we computed the current main employment status of the woman in the exact first 12 months after the first birth (when the first child was 0-12 months old), and in the exact third 12 months after the first birth (when the first child was 2436 months old). If the GSOEP's monthly activity calendar showed that the woman had worked full-time or part-time or was enrolled in education at least five months in the first year after the first birth and at least six months in the third year after the first birth, then we defined her employment status as "working” in the two respective years. If the woman reported that she was on maternity/parental leave, was unemployed, or was a full-time housewife for at least eight months in the first year and at least seven months in the third year after the first birth, then we defined her employment status as "not working” for these respective years" .

In the event-history analysis, we refer to the woman's employment level in the previous calendar year. This variable indicates whether the woman worked full-time, part-time, or was not working in $t-1$. The GSOEP defines full-time work as having

\footnotetext{
${ }^{7}$ We have decided to include employment status (works vs. does not work) rather than employment level (works full-time or part-time or is not working) in the logistic regression models because Akaike's Information Criterion (AIC) test showed that this variable better fits the models of the Western German women. Although the employment level variable better fits the models of the Eastern German woman, for the sake of consistency we have decided to use employment status in the models for the Eastern German women as well.
} 
positive wages and working at least 35 hours per week on average; and part-time work as having positive wages and working less than 35 hours per week, and not working otherwise. In the event history models, we include the lagged employment level because we want to avoid the possible reverse effect of the second birth on women's employment, especially for the women who gave birth in the first half of the year.

\section{Other variables}

Current region - This variable indicates whether the household was located in Eastern or Western Germany at the time of the survey. For 57 women in the sample of 539 women for whom information on the region was missing in the first year after the first birth, the value was imputed based on the woman's observations of region in the consecutive years.

Current marital status - This variable indicates the marital status of the woman in the relevant year. It receives the value one if the woman was legally married or was living with a partner in the relevant year, and the value zero otherwise (i.e., if the woman was single, widowed, divorced, or separated and was not living with a partner). We control for marital status for two reasons. First, the availability of a spouse might increase the odds of a second birth, and the other way around - if the woman does not have a spouse, her chances of giving birth for a second time might decrease. Second, as we are interested in the provision of childcare by people other than the mother, the father of the child or the partner of the mother might be an important source of help, if he is available.

Current self-rated health status - This variable indicates the health status of the woman in the relevant year, as perceived by the woman. It receives the value one if the woman defines her health status as "poor" or "bad," and the value zero if she 
defines it as "satisfactory,” “good,” or “very good.” It is important to control for health status for two reasons. First, women with poor or bad health might be less likely to give birth for a second time. Second, in our study it is important to control for the health status of the woman in year $t$, because it might interact with the availability of domestic help in this year, just before the second birth. Under German $\operatorname{law}^{8}$, a woman is entitled to receive domestic services that are fully covered by her health insurance during pregnancy and one week after childbirth if the woman is very sick or has a very demanding situation in her family, and she has a child under the age of 12 or in need of care, and there is no one else in the household who can do the household chores and the care work. In order to analyze whether the effect of employing domestic help on the transition to a second birth is mediated by the health status of the woman just before the second birth, we will include an interaction term between employing domestic help and the health status variables in the event-history models.

Current educational level - This variable indicates the woman's highest educational level in the relevant year. The GSOEP team recoded the original categories, which are relevant to the German educational system, so that they will be comparable to the international educational level categories (for more details, see Grabka (2011, p. 21)). The recoded variable, which is being used in our analysis, is composed of three dummy variables: less than high school, completed high school, and more than high school. It is important to control for educational level in our analysis, as previous research found that the educational level of the mother has a significant effect on the transition to a second birth (Kreyenfeld, 2002) and on the usage of childcare facilities (Krapf, 2012) in West Germany. Moreover, as previous research found that the

\footnotetext{
${ }^{8}$ Fünftes Buch Sozialgesetzbuch - Gesetzliche Krankenversicherung - vom 20. Dezember 1988.
} 
tendency to outsource household labor and childcare to paid providers affects mostly the fertility of highly educated women, it is important to analyze whether the effect of outsourcing varies by the educational level of the woman.

Age at first birth - This variable indicates the woman's age at the time of the first birth, and is included in the event-history models, also in its quadratic form. ${ }^{9}$ This is an important confounder, because it serves as a proxy for measuring the woman's career commitment. This is because age at first birth affects both transitions to higherorder births (Kuhler et al., 2001; Kreyenfeld, 2002), and is also closely related to educational level and income in the German context, as highly educated Western German women tend to postpone fertility in order to maintain a career; and these characteristics might be related to the tendency to outsource household labor and childcare.

Time since first birth $(t)$ - This variable measures the time that elapsed since the first birth, and is included in the event-history models, also in its quadratic form. Log of the lagged net annual household per capita income (Euro) - This variable represents the combined income, after taxes and government transfers, in the previous year, of all of the individuals in the household, divided by the number of people in the household. As suggested by Kreyenfeld (2002), higher income is expected to positively affect fertility, because high-income families are better able to afford a larger family. Moreover, Rindfuss et al. (1996) posited, from a life-course perspective, that parents will anticipate the relatively high childcare expenses, and will therefore decide to postpone childbearing until the stage in their lives when their income allows for these expenses. Income is an important confounder because it also

\footnotetext{
${ }^{9}$ As the inclusion of a quadratic term of age at first birth showed no significant effect in the logistic regression models, we have decided not to include it in this analysis.
} 
affects the woman's ability and tendency to outsource childcare and household chores.

Log of the lagged annual labor earnings (Euro) - This variable represents the woman’s gross labor earnings in the previous year. Labor earnings include wages and salary from all employment, including training, primary and secondary jobs, and selfemployment; plus income from bonuses, overtime, and profit-sharing. Because both the household income and the woman's labor earnings might be affected by the woman's employment, we include these variables in their lagged form; this avoids the possible effect of a birth in year $t$ on the woman's employment in the same year.

It is important to note that migration background is also an important confounder, because it might affect both the woman's fertility and her tendency to outsource childcare and housework. However, as the inclusion of the migration background variable in our models does not change our results; and as the number of women with migration background in the models for Eastern Germany is quite small, we have decided not to include this variable in the final models.

\section{Results}

Table 2 presents the descriptive statistics of the sample of the 539 women, by region and years after the first birth. ${ }^{10}$ In general, the characteristics of our sample are in line with the general statistics discussed above. As can be seen from this table, higher percentages of the Western German women were married or lived with a partner during the first year and the third year after the first birth (65\% and 78\%, respectively) than the Eastern German women (32\% and 39\%, respectively). Moreover, although the Western and the Eastern German women did not differ in their employment patterns during the first year after the birth of the first child, there were profound

\footnotetext{
${ }^{10}$ The descriptive statistics of the sample of the 1,394 women over person-years are presented in Table
} 3. 
differences in their employment patterns in the third year after the first birth. While in the first year, over $80 \%$ of the women in the two regions did not work, $10 \%-13 \%$ worked part-time, and 5\%-7\% worked full-time. In the third year after the first birth, when the first child was 2-3 years old, $60 \%$ of the Western German women did not work, compared to $36 \%$ of the Eastern German women. In addition, while only $10 \%$ of the Western German women worked full-time, the full-time employment rate among Eastern German women was almost four times higher, at 38\%. Part-time employment did not differ significantly between the two regions in the third year. Meanwhile, no significant differences between the two regions were found in the health status and educational levels of the women. In the first year, 3\%-4\% of the women described their health as poor or bad, compared to $9 \%-11 \%$ in the third year. With regard to education, about $60 \%$ of the women in both regions had a high school degree, and about 25\% of the Western German and 30\% of the Eastern German women had higher education. The rest had less than a high school degree. As the general statistics demonstrate, the age at first birth was higher among the Western German (28.7) than the Eastern German (26.7) women. Moreover, relative to Eastern German women, Western German women lived in households with higher incomes, and they earned higher salaries when they worked.

With regard to sources of help with childcare, about $80 \%$ of the women in the two regions reported over the two years having a spouse who provided at least one weekly hour of childcare. In the two regions, the spouse was found to be the most common source of help with childcare, and the amount of childcare time he provided

[Table 2 here]

did not change much between the two years. However, among those who said they were helped by their spouse, Western German women reported receiving significantly 
less childcare help from their partner than Eastern German women, both in the first and in the third year after the first birth. Overall, Western German partners provided 16.2 and 15.8 hours per week of childcare in the first and the third years, respectively; and Eastern German partners provided 22.7 and 21.6 hours per week, respectively. In addition, 58\% of the Western German women and 53\% of the Eastern German women reported that the child's grandparents provided at least one hour of childcare in the first year after the first birth. By the third year, these figures had risen to $66 \%$ and $61 \%$, respectively. The two regions were not found to differ in the amount of childcare time provided by the grandparents, which was about eight hours per week in the first year and nine hours per week in the third year. When asked whether they had received help with childcare from other relatives and friends, about $17.5 \%$ of the women said they had been helped in the first year and $21 \%$ of the women said they had been helped in the second year, with no differences found between the regions. Other relatives and friends provided about 4.5 hours of childcare per week in the first year and 5.6 hours per week in the second year, in both regions. The most profound differences with regard to sources of help with childcare were found in the use of formal childcare arrangements.

While only 3\% of the Western German women made use of formal childcare facilities in the first year after the first birth, 8\% of the Eastern German women made use of such arrangements. However, among those who used these arrangements in the first year, there was no significant difference in the average amount of time the child spent in childcare: 28.6 hours per week for Western German children and 26.8 hours per week for Eastern German children. However, when the first child was aged 2-3, the differences between the two regions were apparent, both in the usage of these facilities and in the amount of time of the child spent in childcare. While $83 \%$ of the Eastern German women made use of formal childcare arrangements when the child 
was 2-3 years old, only $48 \%$ of the Western German women did so. Moreover, while the average Eastern German child received 29.3 hours per week of childcare from a formal childcare provider, the average Western German child received only 16.8 hours per week of formal care. In order to analyze whether, for example, the help received from grandparents was a substitute when formal childcare is not available, or whether the different sources of help were complementary, rather than substitutes for one another, we used correlation analysis. This analysis showed that, in the first year after the first birth, there was a positive, although weak correlation $\left(\mathrm{p}=.261^{* *}\right)$ between the number of hours of childcare provided by grandparents and the number of hours provided by other relatives in Western Germany. A positive and stronger correlation $\left(\mathrm{p}^{\left.=.531^{* *}\right)}\right.$ between the hours provided by these two sources of help was also found among Eastern German women in the first year after the birth. In the third year after the first birth, when the child was aged 2-3, there was a positive weak correlation $\left(\mathrm{p}=.253^{* *}\right)$ between the hours of childcare invested by the partner and the hours invested by the grandparents in Western Germany. No significant correlation between any of the sources of help was found for Eastern Germany in the third year. These results suggest that the different sources mentioned above are complementary, rather than substitutes for one another. Surprisingly, none of the informal sources of help was found to be a substitute for formal childcare.

\section{[Table 3 here]}

Table 4 presents the average number of hours of childcare received by each source in the first and in the third year after the first birth, by working and nonworking mothers, in the two regions. Mothers who do not receive any help from a certain source receive the value zero in the calculations of the averages. As the table demonstrates, both in Eastern and in Western Germany working mothers outsource childcare more hours than non-working mothers in the first year after the first birth. 
Western German working mothers outsource more hours of childcare to informal care providers in this year, relative to Western German mothers who do not work; and Eastern German working mothers outsource more hours of childcare to formal childcare providers in this year, relative to Eastern German mothers who do not work. In the third year after the first birth working and non-working mothers in the two regions outsource on average the same amount of hours of childcare to all the sources.

[Table 4 here]

The results of our multivariate analysis using logistic regression models, which are presented in Table 5, showed that Western and Eastern German women who were married or were living with a partner in the first and in the third year after the first birth had higher odds of having a second child, relative to non-married women who did not live with a partner. These findings are also supported by the results of the event-history analysis, which are presented in Table 6.

With regard to the effect of the woman's health condition, our logistic models suggest that Western German women whose health was poor or bad in the third year after the first birth were less likely to give birth for a second time, relative to Western German women in good health. The event-history models (Table 6) further showed that, overall, being in poor or bad health during the time period after the first birth reduced the women's propensity to have a second child. Our logistic regression models did not find a significant effect of the mother's educational level in the two years under analysis on the transition to a second birth, but the event-history models, which refer to the whole period between the first and the second birth, showed a positive effect of the mother's educational level on her propensity to have a second child. This result is in line with previous findings regarding the positive educational gradient of the transition to a second birth (Kreyenfeld, 2002). 
The event-history models (Table 6) showed an inverse U-shaped effect of the age of the mother at the time of the first birth on the transition to a second birth, with the odds of a second birth increasing until age 24, and starting to decline at older ages. These models also demonstrated an inverse U-shaped effect of the time elapsed since the first birth, with the maximum shown in the fourth year after the first birth. Moreover, the household income was found to positively affect the transition to a second birth in the first and in the third year after the first birth, but this effect was not found in the event-history models. In both the logistic regression models and the event-history models, the women's salary was not found to affect the transition to a second birth.

[Table 5 here]

As Table 5 demonstrates, the employment status of the mother in the first and in the third year after the first birth was not found to affect her propensity to have another child, either among Eastern German or Western German women. However, our event-history models showed that, not controlling for the ability or tendency to outsource childcare, women who did not work after the first birth had higher odds of having a second child in the next year, relative to women who worked full-time; and that women who worked part-time did not significantly differ from women who worked full-time. These results were not significantly different for Eastern and Western Germany. ${ }^{11}$

Models 1 in Table 5 allowed us to test Hypotheses 1 and 2. Our results from these models confirmed Hypothesis 2, as they demonstrated that, controlling for other characteristics, the more Western German mothers relied on formal and on informal sources of help with childcare, the lower were their odds of having a second child. We

\footnotetext{
${ }^{11}$ The results of this interaction are not presented.
} 
found that every additional hour of care received from the grandparents in the first and third years after the first birth reduces the odds of a second birth among Western German mothers. Moreover, the more time the child spent in formal childcare in the third year, the lower the mother's propensity was to have another child. Models that are not presented, in which we included the sources of help as dummy variables, showed that whether the child was in childcare in the third year did not significantly affect the propensity of Western German mothers to have an additional child. Receiving help with childcare from different sources was not shown to significantly affect the transition to a second birth among Eastern German women. It is important to note, however, that we believe that with a bigger sample size the positive effect of the use of formal childcare by Eastern German mothers might have become significant. Moreover, as can be seen in Table 5, the effect of the hours of childcare received from grandparents is also negative among Eastern German women (although not significant), and the coefficients are not significantly different from those received for Western German women. We believe that even if the negative coefficients of the help received from grandparents among Eastern German women were significant, it would still support our argument regarding the existence of a normative role strain. It is possible that Eastern German first-time mothers who put burden on their parents or their parents in-law, who are presumably younger than the Western German grandparents and are most probably still working, feel also an increase in the normative role strain due to that.

Models in which we included the sources of help as dummy variables (i.e., whether or not the mother received at least one weekly hour of help with childcare from each source $)^{12}$ showed that, if the spouse invested at least one hour of childcare per week in the first year, the odds of having a second child increased significantly

\footnotetext{
12 These models are not presented.
} 
among Eastern German women, but not among Western German mothers. This appears to confirm the importance of a more equal division of household labor and childcare among Eastern German women.

In line with Hypothesis 3, Model 2 in Table 5 showed that the negative effect of the outsourcing of childcare to grandparents in the third year after the first birth, among Western German mothers, is stronger among working women. We found that among Western German women outsourcing childcare responsibilities to grandparents in the third year after the first birth significantly reduced, rather than increased, the propensity of working women to have an additional child, so that each additional hour of childcare provided by grandparents reduced the Western German working women's odds by 0.081 . This effect was not found for Western German women who did not work, although as Table 4 demonstrates, on average Western German nonworking mothers use the same amount of hours of help from grandparents in the third year as the working mothers. Among this group, each additional hour of childcare provided by the grandparents did not affect the odds of having a second child (see Figure 2). This effect also was not found for the Eastern German women, among whom the outsourcing of childcare tasks in the two years did not significantly affect the transition to a second birth, regardless of the mother's employment characteristics. Interestingly, the negative effect of the number of hours the child spent in formal childcare in the third year did not change with the Western German mother's employment characteristics in this year. This suggests that the use of formal childcare is still universally perceived by mothers in Western Germany as unacceptable. Thus, instead of reducing their allocation role strain, using childcare appears to increase their normative role strain, which negatively affects their propensity to have an additional child. In models which are not presented, no significant interactions were 
found between the mother's educational level and the effects of the different sources of help.

Table 6 presents the results of the event-history models, with which we analyze the effect of the outsourcing of household labor on the transition to a second birth. Model 1 lends support to Hypothesis 4, as it demonstrated that—controlling for income, educational level, and other characteristics — the women who outsourced household labor had higher odds of having a second birth than women who did not outsource. Our concern that this positive effect might have been driven by the right of pregnant women who suffer from poor health to receive domestic help paid for by health insurance was dispelled. This is because Model 2 showed that the interaction effect between employing a domestic helper in year $t$ and being in poor or bad health in year $t$ when giving birth for the second time in the same year is insignificant. The results of Model 2 provide no support for Hypothesis 5, as the interaction effect between women's employment and employing a domestic helper was found to be insignificant. Our findings therefore suggest that women feel less burdened by housework regardless of whether they are working, and that this relief in the allocation role strain positively affects their propensity to have an additional child. It is important to note that a model that is not presented found no significant interactions between employing a domestic helper and region, educational level, or household income.

[Table 6 here] 


\section{Summary and conclusions}

The struggle that women face in reconciling their work and family roles is one of the main explanations for the rapid decline in fertility rates in some developed countries. Scholars have further suggested that, if the incompatibility of women's roles were reduced, an increase in both women's labor force participation and fertility would follow. This role incompatibility could be addressed, according to previous studies, through changes in policies related to childcare, parental leave, and labor market arrangements. These policy changes are expected to remove the institutional barriers to balancing work and family roles. Other scholars have suggested that role incompatibility could be reduced through a more egalitarian division of household labor and childcare tasks between the spouses, which would alleviate the burden women bear at home, and might affect their propensity to have an additional child.

In the current study, we investigated whether the practice of outsourcing could be another mechanism for attenuating the negative effect of role incompatibility on fertility. By using the German Socio-Economic Panel (GSOEP) and by employing a life-course perspective, we analyzed how, among women who gave birth for the first time between 1999 and 2006, the ability or tendency to outsource household labor by using domestic help services affects the decision to have a second child. Moreover, by focusing on the first year and the third year after the first birth (i.e., when the first child was aged 0-12 months and 24-36 months, respectively) among women who gave birth for the first time between 2002 to 2006, we analyzed how the mother's characteristics and the different sources of help with childcare available to her in these years affected her odds of having an additional child. These sources of help included both formal childcare arrangements and informal providers from the mother's social network. While taking into account the different cultural and institutional characteristics of Western and Eastern Germany, we derived hypotheses about the 
effect of the tendency to outsource childcare and housework tasks on the transition to a second birth. Our hypotheses are based on Goode’s (1960) role strain theory and suggest that, in addition to allocation role strain, women might feel a normative role strain if they perform a set of roles that are not perceived as appropriate or normative for women by society.

Our results lead us to draw three main conclusions, which are explained in detail below. 1) The strain relief effect of the outsourcing of childcare and housework on fertility is conditioned by the normative environment which defines what can be delegated by women. 2) In societies where the norms strongly associate between the mother's role as the main caregiver and the children's well-being, a wider deployment of childcare facilities may not necessarily increase the usage of such facilities in the short-run. 3) Whether or not the partner contributes to the child's care does not affect fertility in the less egalitarian Western German context, but it does affect fertility in the more egalitarian Eastern German setting.

Our results demonstrate that if there are no normative barriers to the delegation of a task, as in the case of housework, the outsourcing of this task by women will have a positive effect on their tendency to have a second child. This is because the outsourcing of this task reduces the allocation role strain and relieves the burden women experience in the household sphere. However, as the results for the outsourcing of childcare demonstrate, if the norms in the society disapprove the delegation of a certain task, the outsourcing of this task will increase the normative role strain and will negatively affect the mother's propensity to have a second child.

Our results further show that, in line with our expectations, the more a Western German child is being taken care of by people other than the mother, the lower the mother's propensity to have an additional child will be. This means that the delegation or the outsourcing of childcare tasks, both to formal childcare providers 
(when the first child was aged 2-3) and to the grandparents (both when the child was aged 0-1 and when the child was aged 2-3) reduced the odds of a second birth among Western German women. The negative effect of the use of formal childcare among Western German women might also be interpreted by means of trust. It might be that in Eastern Germany, where formal childcare is highly available and well established, women feel less dissonance when they put their child in childcare; while in Western Germany, where the childcare system is not well established, mothers do not trust this system to provide adequate care for their child and might feel higher dissonance when using it. However, the fact that the effect of the use of grandparents, who are supposed to be considered as a trustful source of care, is also negative and significant suggest that there may be a positive effect of the outsourcing of childcare tasks on the normative role strain in societies in which the prevailing norm is that a mother should stay home with her young children, as is the case in Western Germany. Moreover, the negative effect of the time provided by the grandparents might suggest that this behavior also conflicts with the woman's daughter role, as she places a burden on her parents or parents-in-law. Among Eastern German women, however, the time the child spent with other care providers did not produce significant negative effects. The significant negative interaction we found between the Western German mother's employment status and the number of hours of childcare provided by the grandparents lends additional support to our claim that the outsourcing of childcare in this context increases the normative role strain the mothers experience. This is because, based on Goode's theory, we expected that if culture does not matter the outsourcing of childcare should reduce the allocation role strain among both Western and Eastern German working women, and should increase these women's risks of having a second child. However, our results showed that the risk of a second birth among working Western mothers declined with each additional hour of childcare the child received 
from the grandparents. This negative effect was not found for Western German mothers who did not work, or for Eastern German women. The existence of a normative role strain is further implied by the results concerning the outsourcing of household labor. As there are fewer cultural or normative barriers to the outsourcing of housework, the ability of German women to delegate housework responsibilities reduces their allocation role strain, and thus positively affects the transition to a second birth. As Kühhirt and Ludwig (2012) demonstrated, among (Western) German women, the ability to reduce their domestic workload is important, not only in order to increase their fertility, but also in order to reduce their wage penalty and to ensure that they have rewarding careers.

Moreover, the negative effect of the hours the child spends in formal childcare in Western Germany was not found to differ between working and non-working women. This suggests that, as long as there are normative barriers to the use of formal childcare, a wider deployment of such facilities might not necessarily increase the use of these childcare arrangements in the short-term. As Lesthaeghe and Neels (2002) also found, the lagging of the normative "acceptability" factor behind the “availability” and the "profitability” factors in Western Germany may act as a bottleneck, and might postpone the spatial spread of the use of childcare arrangements. Thus, the newly enacted German policy designed to increase the availability of childcare facilities might, at least for a certain period of time, produce an oversupply of these services in Western Germany. Moreover, the greater availability of childcare facilities and the wider use of these arrangements could, at least for a time, reduce rather than increase fertility. This is likely to be the case until a change in the normative expectations of mothers of young children occurs, and the “acceptability” factor catches up to the "availability” and "profitability” factors. Our finding that outsourcing childcare responsibilities to formal service providers does not 
negatively affect the transition to a second birth in Eastern Germany, despite the more intensive use of such facilities in this region, suggests that Eastern German parents are inclined to use formal childcare, irrespective of their characteristics, and that there are no normative barriers to this behavior.

Our results concerning the effect of whether the partner/spouse contributes to the child's care demonstrated that the amount of childcare time invested by the partner in the first and in the third year after the first birth had no effect on the transition to a second birth in Western Germany, regardless of whether the woman was working during this demanding period. Among Eastern German couples, we found that, if the partner contributed at least one hour per week of childcare in the first year after the first birth, the women's propensity to have a second child increased, regardless of whether she was working. However, we did not find a significant effect for the number of hours the spouse invested in childcare on the transition to a second birth. These results for Eastern and Western Germany are in line with the differences in the division of household labor in the two regions, as Eastern German households are more egalitarian than Western German households. These results also support McDonald's (2000) assertion that we can expect gender equity in the household to influence fertility, particularly in contexts of high gender equity. Our results concerning the partner's contribution to childcare and the way this contribution affects the transition to a second birth suggest that structural mechanisms that allow partners to be more involved in the child's care, such as paternal leave policies or more flexible working hours, might serve to increase fertility in Eastern Germany.

Overall, our results demonstrated that, in certain institutional contexts, women in the $21^{\text {st }}$-century developed world are not free to choose how to live their lives, and that they do not act only according to their own preferences, as Hakim (2004) has suggested. Our findings for Western German women showed that, in a sense, 
women's preferences and choices are determined by the institutional contexts in which they are living.

For a reassessment of the existence of a normative role strain, it would be interesting to examine in a future study whether —and, if so, how — the negative effect of the use of sources of help with childcare change over time, following the increase in the provision of childcare facilities in Germany. Moreover, it would be interesting to analyze the relationship between outsourcing and fertility in other institutional contexts that differ in their normative perceptions of women's roles, as well as in their institutional barriers to the reconciliation of work and family roles among women. 


\section{References}

Barone, G. and Mocetti, S. (2011). With a little help from abroad: The effect of lowskilled immigration on the female labour supply. Labour Economics, 18, 5, 664-675.

Becker, P.E. and Moen, P. (1999). Scaling back: Dual-earner couples' work-family strategies. Journal of Marriage and Family, 61: 995-1007.

Brewster, K.L. and Rindfuss, R.R. (2000). Fertility and women’s employment in industrialized nations. Annual Review of Sociology, 26, 271-296.

Bühler, C. and Fratczak, E. 2004. Social capital and fertility intensions: The case of Poland. MPIDR Working Paper WP 2004-012.

Bühler, C. and Fratczak, E. 2005. Learning from others and receiving support: The impact of personal networks on fertility intensions in Poland. MPIDR Working Paper WP 2005-017.

Bühler, C. and Philipov, D. 2005. Social capital related to fertility: Theoretical foundations and empirical evidence from Bulgaria. Vienna Yearbook of Population Research 2005, pp. 53-81.

Chan, A.H. (2006). The effects of full-time domestic workers on married women's economic activity status in Hong Kong, 1981-2001. International Sociology, 21, 1, 133-159.

Coale, A. J. (1973). The demographic transition reconsidered, In: Readings in Population Research Methodology, Vol. 7, chapter 12, pp. 25-96 - 25-98. Chicago: Social Development Center.

Cooke, L. P. (2004). The gendered division of labor and family outcomes in Germany. Journal of Marriage and the Family, 66(5), 1246-1259.

Cooke, L. P. (2008). Gender equity and fertility in Italy and Spain. Journal of Social 
Policy, 38(1), 123-140.

Cortès, P. \& Pan, J. (2009). Outsourcing household production: Demand for foreign domestic helpers and native labor supply in Hong Kong. Unpublished manuscript, University of Chicago.

Cortès, P. and Tessada, J. 2009. Low-skilled immigration and the labor supply of highly educated women. Unpublished manuscript, University of Chicago.

Coser, L. A. (1974). Greedy Institutions: Patterns of Undivided Commitment. New York: The Free Press.

Davis, S.N. and Greenstein, T.N. (2004). Cross-national variations in the division of household labor. Journal of Marriage and Family, 66: 1260-1271.

Del Boca, D. 2002. The effect of child care and part time opportunities on participation and fertility decisions in Italy. Journal of Population Economics, 15, 3, 549-573.

De Ruijter, E. and Van der Lippe, T. (2007). Effects of job features on domestic outsourcing as a strategy for combining paid and domestic work. Work and Occupations, 34, 2, 205-230.

Engelhardt, H., Kögel, T. and Prskawetz, A. (2004). Fertility and women’s employment reconsidered: A macro-level time-series analysis for developed countries. Population Studies, 58, 1, 109-120.

Erler, D. (2009). Germany: taking a Nordic turn?. In: S.B. Kamerman and Moss, P. (Eds.). The Politics of Parental Leave Policies - Children, Parenting, Gender and the Labor Market. (Pp. 119-134).

Ette, A. und Ruckdeschel, K. (2007). Die Oma macht den Unterschied! Der Einfluss institutioneller und informeller Unterstützung für Eltern auf ihre weiteren Kinderwünsche. Zeitschrift für Bevölkerungswissenschaft, 32(1-2): 51-72. 
Farrè, L., González, L. and Ortega, F. (2009). Immigration, family responsibilities, and the labor supply of skilled native women. Ivie Working Paper WP-AD 2009-19.

Fortado, D. and Hock, H. (2008). Immigrant labor, child-care services, and the workfertility trade-off in the United States. IZA discussion paper no. 3506.

Frejka, T. and Calot, G. (2001). Cohort reproductive patterns in low-fertility countries. Population and Development Review, 27(1): 103-132.

Geisler, E. (2010). Müttererwerbstätigkeit. In: J.R. Goldstein, Kreyenfeld, M., Huinink, J., Konietzka, D. and Trappe, H. (Eds.). Familie und Partnerschaft in Ost- und Westdeutschland. (Pp. 11-12). Rostock: Max Planck Institute for Demographic Research.

Goldstein, J.R. and Kreyenfeld, M. (2011). Has East Germany overtaken West Germany? Recent trends in order-specific fertility. Population and Development Review, 37(3): 453-472.

Goode, W.J. (1960). A theory of role strain. American Sociological Review, 25(4): 483-496.

Grabka, M. M. (2011). Codebook for the \$PEQUIV File 1984-2010 - CNEF Variables with Extended Income Information for the SOEP. Berlin: Deutsches Institut für Wirtschaftsforschung (DIW). http://www.diw.de/documents/publikationen/73/diw_01.c.377728.de/diw_data doc_2011-057.pdf

Hakim, C. (2004). Key Issues in Women's Work - Female Diversity and the Polarization of Women's Employment $-2^{\text {nd }}$ Edition. Great Britain: Biddles Ltd.

Hank, K. and Kreyenfeld, M. (2003). A multilevel analysis of child care and women's fertility decisions in Western Germany. Journal of Marriage and Family, 65, 584-596. 
Keim, S., Klärner, A. and Bernardi, L. (2009). Qualifying social influence on fertility intensions - Composition, structure and meaning of fertility-relevant social networks in western Germany. Current Sociology, 57, 6, 888-907.

Kohler, H-P, Skytthe, A. and Christensen, K. (2001). The age at first birth and completed fertility reconsidered: Findings from a sample of identical twins. MPIDR working paper WP2001-006. Max Planck Institute for Demographic Research.

Krapf, S. (2010). Kinderbetreuung. In: J.R. Goldstein, Kreyenfeld, M., Huinink, J., Konietzka, D. and Trappe, H. (Eds.). Familie und Partnerschaft in Ost- und Westdeutschland. (Pp. 13-14). Rostock: Max Planck Institute for Demographic Research.

Krapf, S. (2012). Who uses public child care for two-year-old children? Policy context and usage patterns in Sweden, Finland and Western Germany. Unpublished Manuscript, Max Planck Institute for Demographic Research.

Kravdal, Ø. and Rindfuss, R.R. (2008). Changing relationships between education and fertility: A study of women and men born 1940 to 1964. American Sociological Review, 73, 5, 854-873.

Kremer, M. (2006). The politics of ideals of care: Danish and Flemish child care policy compared. Social Politics, 13(2): 261-285.

Kreyenfeld, M. (2002). Time-squeeze, partner effect or self-selection? An investigation into the positive effect of women's education on second birth risks in West Germany. Demographic Research, 7(2): 15-48.

Kreyenfeld, M. and Bastin, S. (2010). Nichteheliche Elternschaft. In: J.R. Goldstein, Kreyenfeld, M., Huinink, J., Konietzka, D. and Trappe, H. (Eds.). Familie und Partnerschaft in Ost- und Westdeutschland. (p. 28). Rostock: Max Planck Institute for Demographic Research. 
Kreyenfeld, M. and Hank, K. (2000). Does the availability of child care influence the employment of mothers? Findings from western Germany. Population Research and Policy Review, 19: 317-337.

Kreyenfeld, M. and Krapf, S. (2010). Soziale Ungleichheit und Kinderbetreuung Eine Analyse der sozialen und ökonomischen Determinanten der Nutzung von Kindertageseinrichtungen. In: R. Becker and W. Lauterbach (Eds.). Bildung als Privileg. Erklärungen und Befunde zu den Ursachen der Bildungsungleichheit, 4. Auflage. (Pp. 107-123). Wiesbaden: VS Verlag.

Kühhirt, M. \& Ludwig, V. (2012). Domestic work and the wage penalty for motherhood in West Germany. Journal of Marriage and Family, 74: 186-200.

Lesthaeghe, R. and Neels, K. (2002). From the first to the second demographic transition: An interpretation of the spatial continuity of demographic innovation in France, Belgium and Switzerland. European Journal of Population, 18: 325360.

Marks, S.R. (1977). Multiple roles and role strain: Some notes on human energy, time and commitment. American Sociological Review, 42: 921-936.

Marks, S.R. and MacDermid, S.M. (1996). Multiple roles and the self: A theory of role balance. Journal of Marriage and Family, 58(2): 417-432.

McDonald, P. (2000). Gender equity in theories of fertility transition. Population and Development Review, 26(3): 427-439.

Olah, L. S. (2003). Gendering fertility: second births in Sweden and Hungary. Population Research and Policy Review, 22(2), 171-200.

Oropesa, R.S. (1993). Using the service economy to relive the double burden: Female labor force participation and service purchases. Journal of Family Issues, 14, 3, 438-473. 
Philipov, D. and Shkolnikov, V. (2001). Fertility intensions and coping strategies Results from the 1998 round of the Russian longitudinal monitoring survey. Paper presented at the Population Association of America Annual Meeting 2001, Washington, DC.

Philipov, D., Spéder, Z. and Billari, F.C. (2006). Soon, Later, or Ever? The Impact of Anomie and Social Capital on Fertility Intentions in Bulgaria (2002) and Hungary (2001). Population Studies, 60, 3, 289-308.

Pollak, Robert A. 1985. A transaction cost approach to families and households. Journal of Economic Literature, 23(2): 581-608.

Rindfuss, R.R. and Brewster, K.L. (1996). Childrearing and fertility. Population and Development Review, Vol. 22, Suppelement: Fertility in the United States: New Patterns, New Theories, pp. 258-289.

Rindfuss, R.R., Guzzo, K.B., and Morgan, S.P. (2003). The changing institutional context of low fertility. Population Research and Policy Review, 22: 411-438.

Rindfuss, R.R., Morgan, S.P. and Offutt, K. (1996). Education and the changing age pattern of American fertility: 1963-1989. Demography, 33(3): 277-290.

Rosenfeld, R.A., Trappe, H. and Gornick, J.C. (2004). Gender and work in Germany: Before and after reunification. Annual Review of Sociology, 30: 103-124.

Schober, P.S. (2012). Gender equality and outsourcing of domestic Work, childbearing, and relationship stability among British Couples. Journal of Family Issues, DOI: 10.1177/0192513X11433691.

Sieber, S.D. (1974). Toward a theory of role accumulation. American Sociological Review, 39: 567-578.

Steiner, V. and Wrohlich, K. (2004). Household taxation, income splitting and labor 
supply incentives - a microsimulation study for Germany. DIW Discussion Paper (421).

Torr, B.M. and Short, S.E. (2004). Second births and the second shift: A research note on gender equity and fertility. Population and Development Review, 30(1): 109130.

Trappe, H. and Sørensen, A. (2006). Economic relations between women and their partners: An East and West German comparison after reunification. Feminist Economics, 12(4): 643-665.

Van der Lippe, T., Tijdens, K. and De Ruijter, E. (2004). Outsourcing of domestic tasks and time-saving effects. Journal of Family Issues, 25, 2, 216-240.

Yeoh, B.S., Huang, S. and Gonzalez, J. (1999). Migrant female domestic workers: Debating the economic, social and political impact in Singapore. International Migration Review, 33, 1, 0114-0136. 
Figures and Tables 
Figure 1: Percent of German women who think that women should work outside the home full-time, part-time or not at all.

- Full-time $\square$ Part-time $\square$ Stay at home

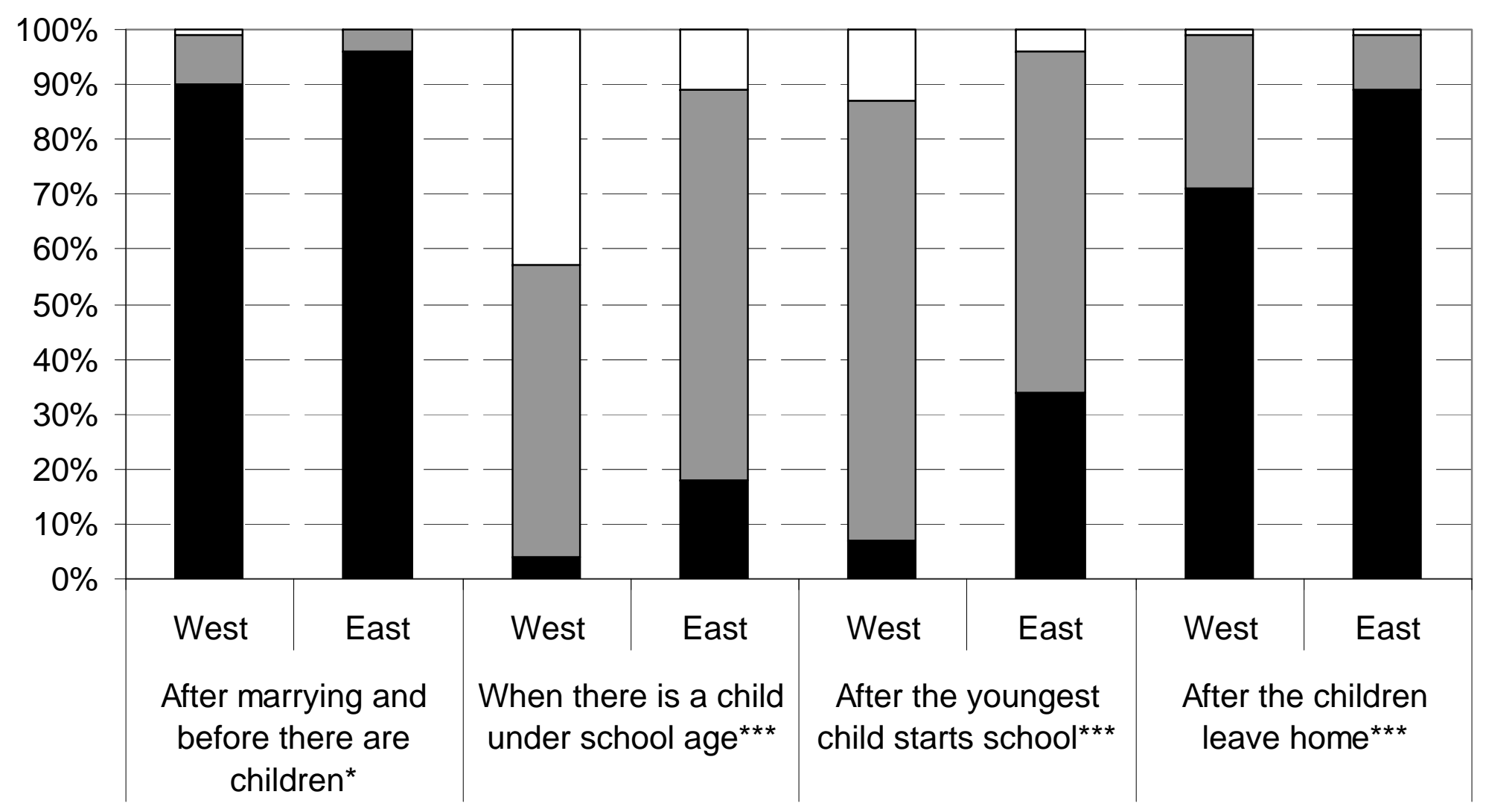

Source: Own calculations, ISSP 2002

${ }^{*} \mathrm{p}<.05 \quad * * * \mathrm{p}<.001$ (Significant differences between Western and Eastern Germany according to chi ${ }^{2}$ test) 
Figure 2: The Odds of giving birth for the $2^{\text {nd }}$ time among Western German women, by employment status and the number of weekly hours of childcare provided by grandparents in the third year after the first birth

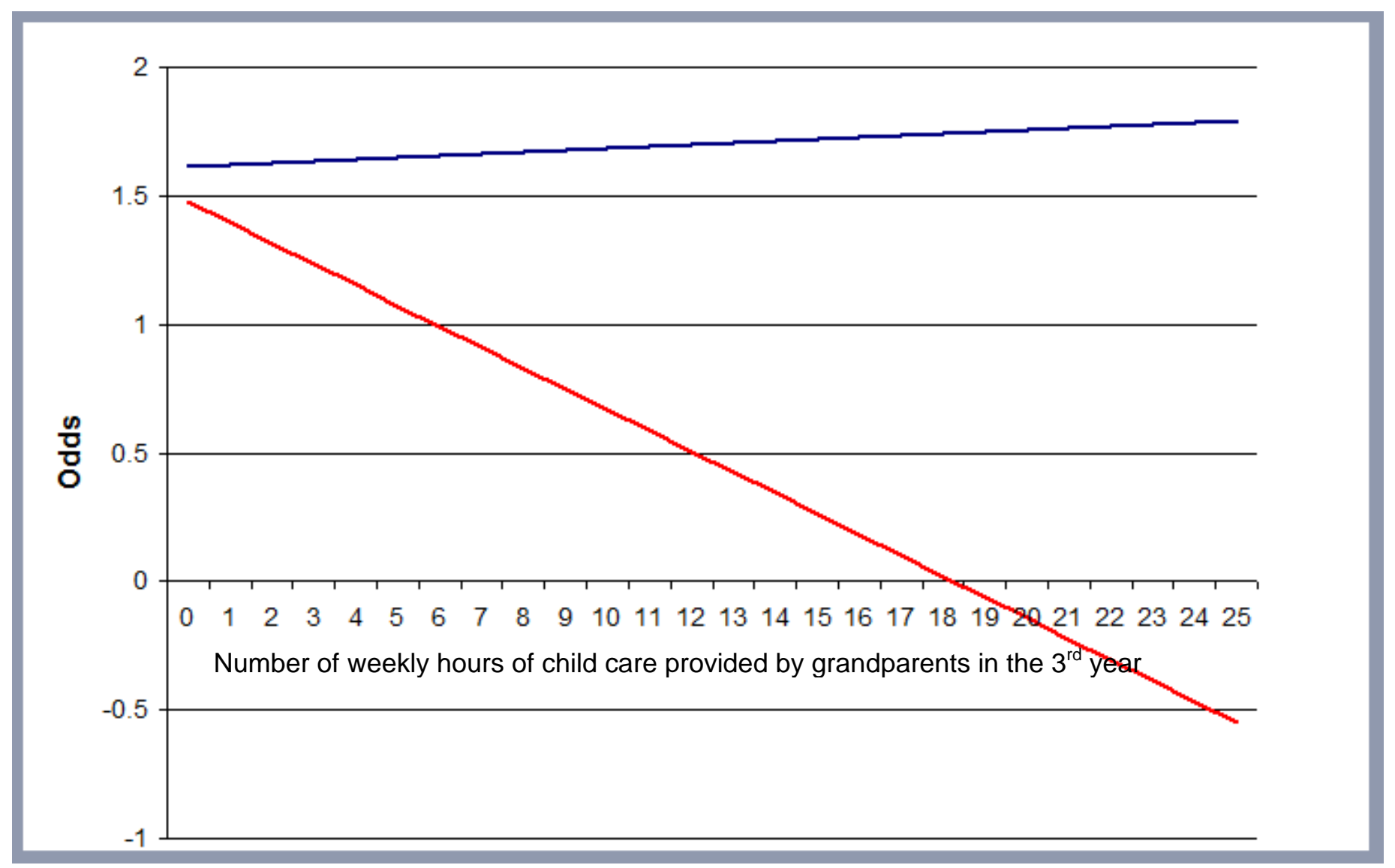


Table 1. Percent of women who agree or strongly agree

\begin{tabular}{|l|c|c|}
\hline & $\begin{array}{c}\text { Western Germany } \\
\text { (N=485) }\end{array}$ & $\begin{array}{c}\text { Eastern Germany } \\
\text { (N=210) }\end{array}$ \\
\hline $\begin{array}{l}\text { A working mother can establish just as } \\
\text { warm and secure a relationship with her } \\
\text { children as a mother who does not } \\
\text { work }\end{array}$ & $84^{* * *}$ & 95 \\
\hline $\begin{array}{l}\text { A pre-school child is likely to suffer if his } \\
\text { or her mother works }\end{array}$ & $51^{* * *}$ & 28 \\
\hline $\begin{array}{l}\text { Family life suffers when the woman has a } \\
\text { full-time job }\end{array}$ & $48^{* * *}$ & 26 \\
\hline $\begin{array}{l}\text { A job is all right, but what most women } \\
\text { really want is a home and children }\end{array}$ & $23^{*}$ & 24 \\
\hline $\begin{array}{l}\text { Being a housewife is just as fulfilling as } \\
\text { working for pay }\end{array}$ & $36^{* *}$ & 86 \\
\hline $\begin{array}{l}\text { Having a job is the best way for a woman } \\
\text { to be an independent person }\end{array}$ & 83 & 93 \\
\hline $\begin{array}{l}\text { Both the man and woman should } \\
\text { contribute to the household income }\end{array}$ & $69^{* * *}$ & 14 \\
\hline $\begin{array}{l}\text { A man's job is to earn money; a woman's } \\
\text { job is to look after the home and family }\end{array}$ & 21 & 68 \\
\hline $\begin{array}{l}\text { Men ought to do a larger share of } \\
\text { household work than they do now }\end{array}$ & 68 & 67 \\
\hline $\begin{array}{l}\text { Men ought to do a larger share of } \\
\text { childcare than they do now }\end{array}$ & $75^{*}$ & \\
\hline
\end{tabular}

Source: Own calculations, ISSP 2002.

${ }^{*} \mathrm{p}<.05 ;{ }^{* *} \mathrm{p}<.01 ; * * * \mathrm{p}<.001$ (Significant differences between Western and Eastern Germany according to chi $^{2}$ test) 
Table 2: Descriptive statistics of the sample of the 539 women, by region and years after $1^{\text {st }}$ birth

\begin{tabular}{|c|c|c|c|c|}
\hline & \multicolumn{2}{|c|}{$1^{\text {st }}$ year } & \multicolumn{2}{|c|}{$3^{\text {rd }}$ year } \\
\hline & $\begin{array}{c}\text { West } \\
(\mathrm{N}=392)\end{array}$ & $\begin{array}{c}\text { East } \\
(\mathrm{N}=147)\end{array}$ & $\begin{array}{c}\text { West } \\
(\mathrm{N}=347)\end{array}$ & $\begin{array}{c}\text { East } \\
(\mathrm{N}=132)\end{array}$ \\
\hline & \multicolumn{2}{|c|}{$\%$} & \multicolumn{2}{|c|}{$\%$} \\
\hline \multicolumn{5}{|l|}{ Current marital status } \\
\hline Married or living with a partner & $65 * * *$ & 32 & $78 * * *$ & 39 \\
\hline Other & 44 & 72 & 23 & 61 \\
\hline \multicolumn{5}{|l|}{ Current self-rated health status } \\
\hline Poor or bad & 3 & 4 & 9 & 11 \\
\hline Satisfactory, good, or very good & 97 & 96 & 91 & 89 \\
\hline \multicolumn{5}{|l|}{ Educational level } \\
\hline Less than high school & 15 & 12 & 14 & 9 \\
\hline High school & 59 & 58 & 61 & 60 \\
\hline More than high school & 26 & 30 & 25 & 31 \\
\hline \multicolumn{5}{|l|}{ Current employment status } \\
\hline Does not work & 82 & 83 & $60 * * *$ & 36 \\
\hline Works part-time & 13 & 10 & 30 & 26 \\
\hline Works full-time & 5 & 7 & 10 & 38 \\
\hline \multicolumn{5}{|l|}{$\begin{array}{l}\text { Spouse provides at least one hour per } \\
\text { week of childcare }\end{array}$} \\
\hline Yes & 80 & 74 & 81 & 83 \\
\hline No & 20 & 26 & 19 & 17 \\
\hline \multicolumn{5}{|l|}{$\begin{array}{l}\text { Grandparents provide at least one hour } \\
\text { per week of childcare }\end{array}$} \\
\hline Yes & 58 & 53 & 66 & 61 \\
\hline No & 42 & 47 & 34 & 39 \\
\hline \multicolumn{5}{|l|}{$\begin{array}{l}\text { Other relatives or friends provide at least } \\
\text { one hour per week of childcare }\end{array}$} \\
\hline Yes & 19 & 16 & 21 & 21 \\
\hline No & 81 & 84 & 79 & 79 \\
\hline \multicolumn{5}{|l|}{$\begin{array}{l}\text { A formal childcare provider provides at } \\
\text { least one hour per week of childcare }\end{array}$} \\
\hline Yes & $3 * *$ & 8 & $48^{* * *}$ & 83 \\
\hline \multirow[t]{2}{*}{ No } & 97 & 92 & 52 & 17 \\
\hline & \multicolumn{2}{|c|}{ Mean } & \multicolumn{2}{|c|}{ Mean } \\
\hline Age at first birth & $28.7 * * *$ & 26.7 & $28.76 * * *$ & 26.95 \\
\hline $\begin{array}{l}\text { Annual household per capita income } \\
\text { (Euro) (t-1) }\end{array}$ & $17,045^{* * *}$ & 12,446 & $11,529 * * *$ & 8,905 \\
\hline $\begin{array}{l}\text { Annual woman's labor earnings (Euro) } \\
(\mathrm{t}-1)\end{array}$ & $21,561 * * *$ & 15,149 & $5,380 * * *$ & 5,819 \\
\hline \multicolumn{5}{|l|}{$\begin{array}{l}\text { Number of weekly hours of childcare } \\
\text { provided by^}\end{array}$} \\
\hline The spouse & $16.2 * *$ & 22.7 & $15.8 * *$ & 21.6 \\
\hline The grandparents & 7.7 & 9.0 & 10.0 & 9.0 \\
\hline Other relatives and friends & 4.7 & 4.4 & 5.6 & 5.6 \\
\hline Formal childcare provider & 28.6 & 26.8 & $16.8 * * *$ & 29.3 \\
\hline
\end{tabular}

${ }^{*} \mathrm{p}<.05{ }^{* *} \mathrm{p}<.01 \quad{ }^{* * *} \mathrm{p}<.001$ (significant differences between East and West according to $\mathrm{Chi}^{2}$ test (for percentages) or t-test (for means)).

$\wedge$ Zero hours are not included in these calculations. 
Table 3: Descriptive statistics of the sample of the 1,394 women, computed over person- years $(\mathrm{N}$ person-years $=8,440$ )

\begin{tabular}{|l|c|}
\hline & $\mathbf{\%}$ \\
\hline Region (t) & 26 \\
\hline East & 74 \\
\hline West & \\
\hline Marital status (t) & 40 \\
\hline Married or live with a partner & 60 \\
\hline Other & \\
\hline Self-rated health status (t) & 7 \\
\hline Poor or bad & 93 \\
\hline Satisfactory, good or very good & \\
\hline Educational level (t) & 14 \\
\hline Less than high school & 62 \\
\hline High school & 24 \\
\hline More than high school & \\
\hline Employment status (t-1) & 34 \\
\hline Not working & 46 \\
\hline Part-time & 20 \\
\hline Full-time & \\
\hline Employs domestic help (t) & 4 \\
\hline Yes, regularly or occasionally & 96 \\
\hline No & Mean (SD) \\
\hline & 27.98 \\
\hline Age at first birth & $(5.21)$ \\
\hline Time since first birth & 3.13 \\
& $(2.60)$ \\
\hline Annual household per capita income (t-1) (Euro) & 11,771 \\
& $(6,584.3)$ \\
\hline Annual woman's labor earnings (t-1) (Euro) & \\
\hline & \\
\hline & \\
\hline & \\
\hline & \\
\hline & \\
\hline
\end{tabular}


Table 4: The average number of weekly hours of childcare provided by different sources, among working and non-working mothers, by region and year after the first birth^

\begin{tabular}{|l|c|c|c|c|}
\hline & \multicolumn{2}{|c|}{ West - 1 $^{\text {st }}$ year } & \multicolumn{2}{c|}{ East - ${ }^{\text {st }}$ year } \\
\hline & Works & $\begin{array}{c}\text { Does not } \\
\text { work }\end{array}$ & Works & $\begin{array}{c}\text { Does not } \\
\text { work }\end{array}$ \\
\hline All sources & $28.8^{* * *}$ & 16.6 & $38.7^{*}$ & 20.2 \\
\hline The spouse & 15.6 & 12.3 & 22.4 & 14.8 \\
\hline The grandparents & $7.7^{*}$ & 3.8 & 7.6 & 4.1 \\
\hline Other relatives and friends & $2.2^{*}$ & 0.6 & 0.9 & 0.7 \\
\hline Formal childcare provider & 3.6 & 0.2 & $7.8^{*}$ & 0.8 \\
\hline
\end{tabular}

\begin{tabular}{|l|c|c|c|c|}
\hline & \multicolumn{2}{|c|}{ West $-3^{\text {rd }}$ year } & \multicolumn{2}{c|}{ East $-3^{\text {rd }}$ year } \\
\hline & Works & $\begin{array}{c}\text { Does not } \\
\text { work }\end{array}$ & Works & $\begin{array}{c}\text { Does not } \\
\text { work }\end{array}$ \\
\hline All sources & 30.7 & 25.5 & 48.6 & 47.4 \\
\hline The spouse & 12.8 & 12.4 & 16.6 & 17.9 \\
\hline The grandparents & 7.5 & 5.9 & 4.6 & 5.3 \\
\hline Other relatives and friends & 0.9 & 0.7 & 0.6 & 0.8 \\
\hline Formal childcare provider & 9.7 & 6.6 & 26.7 & 23.5 \\
\hline
\end{tabular}

${ }^{*} \mathrm{p}<.05 * * * \mathrm{p}<.001$ (significant differences between East and West according to t-test).

$\wedge$ Zero hours are included in these calculations. 
Table 5. Parameter estimates of logistic regression models predicting the odds of a second birth among Eastern and Western German women, by women's characteristics in the first and third years after the first birth

\begin{tabular}{|c|c|c|c|c|c|c|c|c|}
\hline & \multicolumn{4}{|c|}{ West German Women } & \multicolumn{4}{|c|}{ East German Women } \\
\hline & \multicolumn{2}{|c|}{$1^{\text {st }}$ year } & \multicolumn{2}{|c|}{$3^{\text {rd }}$ year } & \multicolumn{2}{|c|}{$1^{\text {st }}$ year } & \multicolumn{2}{|c|}{$3^{\text {rd }}$ year } \\
\hline & Model 1 & Model 2 & Model 1 & Model 2 & Model 1 & Model 2 & Model 1 & Model 2 \\
\hline \multicolumn{9}{|l|}{ Marital status } \\
\hline $\begin{array}{l}\text { Married or live } \\
\text { with a partner }\end{array}$ & $\begin{array}{l}.847 * * * \\
(.264)\end{array}$ & $\begin{array}{l}.827 * * \\
(.265)\end{array}$ & $\begin{array}{l}.713 * \\
(.365)\end{array}$ & $\begin{array}{l}.747 * \\
(.374)\end{array}$ & $\begin{array}{c}2.062^{* * * *} \\
(.530)\end{array}$ & $\begin{array}{c}2.058 * * * \\
(.542)\end{array}$ & $\begin{array}{c}2.312 * * * \\
(.603)\end{array}$ & $\begin{array}{c}2.321^{* * *} \\
(.626)\end{array}$ \\
\hline Other & Ref. & Ref. & Ref. & Ref. & Ref. & Ref. & Ref. & Ref. \\
\hline \multicolumn{9}{|l|}{$\begin{array}{l}\text { Self-rated } \\
\text { health status } \\
\end{array}$} \\
\hline Poor or bad & $\begin{array}{l}-.555 \\
(.725)\end{array}$ & $\begin{array}{l}-.551 \\
(.725)\end{array}$ & $\begin{array}{c}-1.166^{*} \\
(.528)\end{array}$ & $\begin{array}{c}-1.202^{*} \\
(.549)\end{array}$ & $\begin{array}{c}.439 \\
(1.149)\end{array}$ & $\begin{array}{c}.233 \\
(1.181)\end{array}$ & $\begin{array}{c}.865 \\
(.744)\end{array}$ & $\begin{array}{c}.796 \\
(.770)\end{array}$ \\
\hline $\begin{array}{l}\text { Satisfactory, } \\
\text { good, or very } \\
\text { good }\end{array}$ & Ref. & Ref. & Ref. & Ref. & Ref. & Ref. & Ref. & Ref. \\
\hline \multicolumn{9}{|l|}{$\begin{array}{l}\text { Educational } \\
\text { level }\end{array}$} \\
\hline $\begin{array}{l}\text { Less than high } \\
\text { school }\end{array}$ & Ref. & Ref. & Ref. & Ref. & Ref. & Ref. & Ref. & Ref. \\
\hline High school & $\begin{array}{l}-.349 \\
(.377) \\
\end{array}$ & $\begin{array}{l}-.328 \\
(.379) \\
\end{array}$ & $\begin{array}{l}-.060 \\
(.406) \\
\end{array}$ & $\begin{array}{l}-.080 \\
(.410) \\
\end{array}$ & $\begin{array}{l}-.585 \\
(.771) \\
\end{array}$ & $\begin{array}{l}-.413 \\
(.813)\end{array}$ & $\begin{array}{l}-1.125 \\
(1.009)\end{array}$ & $\begin{array}{l}-1.238 \\
(1.102) \\
\end{array}$ \\
\hline $\begin{array}{l}\text { More than high } \\
\text { school }\end{array}$ & $\begin{array}{c}.115 \\
(.452)\end{array}$ & $\begin{array}{l}.152 \\
(.454) \\
\end{array}$ & $\begin{array}{l}-.016 \\
(.507)\end{array}$ & $\begin{array}{c}.001 \\
(.516)\end{array}$ & $\begin{array}{c}.349 \\
(.933)\end{array}$ & $\begin{array}{c}.527 \\
(.977)\end{array}$ & $\begin{array}{c}-.523 \\
(1.191)\end{array}$ & $\begin{array}{c}-.590 \\
(1.274)\end{array}$ \\
\hline $\begin{array}{l}\text { Age at first } \\
\text { birth }\end{array}$ & $\begin{array}{c}-.097 * * \\
(.031)\end{array}$ & $\begin{array}{c}-.099 * * \\
(.031)\end{array}$ & $\begin{array}{l}-.060 \\
(.033)\end{array}$ & $\begin{array}{l}-.069 * \\
(.034)\end{array}$ & $\begin{array}{c}-.234 * * \\
(.079)\end{array}$ & $\begin{array}{c}-.232 * * \\
(.082)\end{array}$ & $\begin{array}{l}-.135 \\
(.084)\end{array}$ & $\begin{array}{l}-.145 \\
(.088)\end{array}$ \\
\hline $\begin{array}{l}\text { Log of } \\
\text { household per } \\
\text { capita income }\end{array}$ & $\begin{array}{l}.700^{*} \\
(.314)\end{array}$ & $\begin{array}{l}.675 * \\
(.315)\end{array}$ & $\begin{array}{c}1.443 * * * \\
(.425)\end{array}$ & $\begin{array}{c}1.435 * * * \\
(.431)\end{array}$ & $\begin{array}{l}1.710 * \\
(.729)\end{array}$ & $\begin{array}{l}1.726 * \\
(.769)\end{array}$ & $\begin{array}{l}-.292 \\
(.760)\end{array}$ & $\begin{array}{l}-.122 \\
(.772)\end{array}$ \\
\hline
\end{tabular}




\begin{tabular}{|c|c|c|c|c|c|c|c|c|}
\hline$($ Euro) $(\mathrm{t}-1)$ & & & & & & & & \\
\hline $\begin{array}{l}\text { Log of woman's } \\
\text { labor earnings } \\
\text { (Euro) (t-1) }\end{array}$ & $\begin{array}{l}.029 \\
(.035)\end{array}$ & $\begin{array}{l}.030 \\
(.391)\end{array}$ & $\begin{array}{l}.016 \\
(.025)\end{array}$ & $\begin{array}{l}.015 \\
(.027)\end{array}$ & $\begin{array}{c}.007 \\
(.059)\end{array}$ & $\begin{array}{l}.001 \\
(.062)\end{array}$ & $\begin{array}{c}.002 \\
(.047)\end{array}$ & $\begin{array}{c}.004 \\
(.050)\end{array}$ \\
\hline \multicolumn{9}{|l|}{$\begin{array}{l}\text { Employment } \\
\text { status }\end{array}$} \\
\hline Works & $\begin{array}{c}-.140 \\
(.332)\end{array}$ & $\begin{array}{l}-.149 \\
(.492)\end{array}$ & $\begin{array}{l}-.170 \\
(.349)\end{array}$ & $\begin{array}{l}-.139 \\
(.579)\end{array}$ & $\begin{array}{l}.320 \\
(.676)\end{array}$ & $\begin{array}{c}-.948 \\
(1.103)\end{array}$ & $\begin{array}{c}.707 \\
(.728)\end{array}$ & $\begin{array}{c}1.002 \\
(1.301)\end{array}$ \\
\hline Does not work & Ref. & Ref. & Ref. & Ref. & Ref. & Ref. & Ref. & Ref. \\
\hline \multicolumn{9}{|l|}{$\begin{array}{l}\text { Number of } \\
\text { weekly hours of } \\
\text { child care } \\
\text { provided by^ }\end{array}$} \\
\hline The spouse & $\begin{array}{c}.008 \\
(.009)\end{array}$ & $\begin{array}{c}.006 \\
(.012)\end{array}$ & $\begin{array}{c}.002 \\
(.010)\end{array}$ & $\begin{array}{l}-.015 \\
(.013) \\
\end{array}$ & $\begin{array}{c}.010 \\
(.011) \\
\end{array}$ & $\begin{array}{l}.004 \\
(.012)\end{array}$ & $\begin{array}{c}.004 \\
(.014)\end{array}$ & $\begin{array}{c}.023 \\
(.035)\end{array}$ \\
\hline The grandparents & $\begin{array}{l}-.039^{*} \\
(.019)\end{array}$ & $\begin{array}{l}-.044 \\
(.025)\end{array}$ & $\begin{array}{l}.038^{*} \\
(.019)\end{array}$ & $\begin{array}{c}.007 \\
(.026)\end{array}$ & $\begin{array}{l}-.010 \\
(.031)\end{array}$ & $\begin{array}{l}-.045 \\
(.056)\end{array}$ & $\begin{array}{l}-.065 \\
(.038)\end{array}$ & $\begin{array}{c}.000 \\
(.048)\end{array}$ \\
\hline $\begin{array}{l}\text { Formal childcare } \\
\text { provider }\end{array}$ & $\begin{array}{c}.002 \\
(.018)\end{array}$ & $\begin{array}{l}.101 \\
(.147)\end{array}$ & $\begin{array}{l}-.033^{*} \\
(.014)\end{array}$ & $\begin{array}{l}-.037 \\
(.023)\end{array}$ & $\begin{array}{l}.027 \\
(.028)\end{array}$ & $\begin{array}{l}.019 \\
(.044)\end{array}$ & $\begin{array}{l}.003 \\
(.018)\end{array}$ & $\begin{array}{l}-.024 \\
(.034)\end{array}$ \\
\hline \multicolumn{9}{|l|}{ Interactions } \\
\hline $\begin{array}{l}\text { Work X hours } \\
\text { provided by } \\
\text { spouse }\end{array}$ & & $\begin{array}{l}.006 \\
(.019)\end{array}$ & & $\begin{array}{c}.034 \\
(.021)\end{array}$ & & $\begin{array}{l}.043 \\
(.034)\end{array}$ & & $\begin{array}{l}.023 \\
(.039)\end{array}$ \\
\hline $\begin{array}{l}\text { Work X hours } \\
\text { provided by } \\
\text { grandparents }\end{array}$ & & $\begin{array}{c}.012 \\
(.038)\end{array}$ & & $\begin{array}{l}-.088^{*} \\
(.040)\end{array}$ & & $\begin{array}{l}-.020 \\
(.083)\end{array}$ & & $\begin{array}{l}-.111 \\
(.068)\end{array}$ \\
\hline $\begin{array}{l}\text { Work X hours } \\
\text { provided by } \\
\text { formal childcare }\end{array}$ & & $\begin{array}{l}-.102 \\
(.148)\end{array}$ & & $\begin{array}{c}.002 \\
(.029)\end{array}$ & & $\begin{array}{l}.027 \\
(.061)\end{array}$ & & $\begin{array}{c}.036 \\
(.041)\end{array}$ \\
\hline
\end{tabular}




\begin{tabular}{|l|c|c|c|c|c|c|c|c|}
\hline provider & & & & & & \\
\hline Constant & 2.328 & 2.402 & 1.310 & 1.616 & 4.924 & 4.997 & 2.350 & 2.485 \\
\hline $\begin{array}{l}-2 \text { Log- } \\
\text { likelihood }\end{array}$ & 408.8 & 406.9 & 324.8 & 316.2 & 133.9 & 128.4 & 97.4 & 94.1 \\
\hline Df & 12 & 16 & 12 & 16 & 12 & 16 & 12 & 16 \\
\hline N (Women) & 321 & 321 & 274 & 274 & 125 & 125 & 108 & 108 \\
\hline N (Events) & 148 & 148 & 110 & 110 & 49 & 49 & 32 \\
\hline
\end{tabular}

${ }^{*} \mathrm{p}<.05,{ }^{* *} \mathrm{p}<.01,{ }^{* * *} \mathrm{p}<.001$

$\wedge$ Due to the low levels provided, the help from other relatives or friends and its interaction with employment status are controlled for but not presented in the table. 
Table 6: Estimates of the discrete-time event-history models for the effect of hiring domestic help services and of other covariates on the transition to a second birth

\begin{tabular}{|c|c|c|}
\hline & Model 1 & Model 2 \\
\hline \multicolumn{3}{|l|}{ Region (t) } \\
\hline East & $\begin{array}{l}-.219 \\
(.149)\end{array}$ & $\begin{array}{l}-.212 \\
(.149)\end{array}$ \\
\hline West & Ref. & Ref. \\
\hline \multicolumn{3}{|l|}{ Marital status ( $t$ ) } \\
\hline Married or live with a partner & $\begin{array}{l}.918 * * * \\
(.151)\end{array}$ & $\begin{array}{c}.920 * * * \\
(.151)\end{array}$ \\
\hline Other & Ref. & Ref. \\
\hline \multicolumn{3}{|l|}{ Self-rated health status $(t)$} \\
\hline Poor or bad & $\begin{array}{l}-.631^{*} \\
(.270)\end{array}$ & $\begin{array}{l}-.595^{*} \\
(.278)\end{array}$ \\
\hline Satisfactory, good, or very good & Ref. & Ref. \\
\hline \multicolumn{3}{|l|}{ Educational level $(t)$} \\
\hline Less than high school & $\begin{array}{l}-.521^{*} \\
(.220)\end{array}$ & $\begin{array}{l}-.522 * \\
(.220)\end{array}$ \\
\hline High school & $\begin{array}{c}-.385^{* *} \\
(.133)\end{array}$ & $\begin{array}{c}-.392 * * \\
(.133)\end{array}$ \\
\hline More than high school & Ref. & Ref. \\
\hline Age at first birth & $\begin{array}{l}.334^{* *} \\
(.127)\end{array}$ & $\begin{array}{l}.329 * * \\
(.127)\end{array}$ \\
\hline Age at first birth ${ }^{2}$ & $\begin{array}{c}-.007^{* *} \\
(.002)\end{array}$ & $\begin{array}{c}-.007 * * \\
(.002)\end{array}$ \\
\hline Time since first birth & $\begin{array}{c}1.243^{* * *} \\
(.123)\end{array}$ & $\begin{array}{c}1.244^{* * *} \\
(.123)\end{array}$ \\
\hline Time since first birth ${ }^{2}$ & $\begin{array}{c}-.163 * * * \\
(.017)\end{array}$ & $\begin{array}{c}-.163^{* * *} \\
(.017)\end{array}$ \\
\hline $\begin{array}{l}\text { Log of annual household per capita income (t-1) } \\
\text { (Euro) }\end{array}$ & $\begin{array}{l}-.190 \\
(.149)\end{array}$ & $\begin{array}{l}-.185 \\
(.150)\end{array}$ \\
\hline $\begin{array}{l}\text { Log of annual woman’s labor earnings ( } t-1) \\
\text { (Euro) }\end{array}$ & $\begin{array}{c}.025 \\
(.024)\end{array}$ & $\begin{array}{c}.023 \\
(.024)\end{array}$ \\
\hline \multicolumn{3}{|l|}{ Employment level $(t-1)$} \\
\hline Not working & $\begin{array}{l}.907^{*} \\
(.383)\end{array}$ & $\begin{array}{l}.880^{*} \\
(.390)\end{array}$ \\
\hline Part-time & $\begin{array}{c}.382 \\
(.198)\end{array}$ & $\begin{array}{l}.411^{*} \\
(.210)\end{array}$ \\
\hline Full-time & Ref. & Ref. \\
\hline \multicolumn{3}{|l|}{ Employs domestic help (t) } \\
\hline Yes, regularly or occasionally & $\begin{array}{l}.586 * \\
(.252)\end{array}$ & $\begin{array}{c}.673 \\
(.539)\end{array}$ \\
\hline No & Ref. & Ref. \\
\hline Employs domestic help ( $t$ ) X Health status & & $\begin{array}{c}-.447 \\
(1.131)\end{array}$ \\
\hline Employs domestic help ( $t$ ) X Not working & & $\begin{array}{c}.501 \\
(.706)\end{array}$ \\
\hline Employs domestic help ( $t$ ) X Works part-time & & $\begin{array}{l}-.353 \\
(.636)\end{array}$ \\
\hline
\end{tabular}




\begin{tabular}{|l|c|c|}
\hline Constant & -6.863 & -6.833 \\
\hline-2 Log-likelihood & 2159.2 & 2156.8 \\
\hline Df & 14 & 17 \\
\hline $\mathrm{N}$ (Person years) & 3,990 & 3,990 \\
\hline $\mathrm{N}$ (Events) & 369 & 369 \\
\hline
\end{tabular}

${ }^{*} \mathrm{p}<.05,{ }^{* *} \mathrm{p}<.01,{ }^{* * *} \mathrm{p}<.001$ 